\title{
A Model of the Sustainable Management of the Natural Environment in National Parks-A Case Study of National Parks in Poland
}

\author{
Piotr Oleśniewicz ${ }^{1}$, Sławomir Pytel ${ }^{2, *}$ (]) Julita Markiewicz-Patkowska ${ }^{3}$, Adam R. Szromek ${ }^{4}(\mathbb{D}$ \\ and Soňa Jandová ${ }^{5}$ \\ 1 Faculty of Physical Education, University School of Physical Education in Wrocław, al. Ignacego Jana \\ Paderewskiego 35, 51-612 Wrocław, Poland; piotr.olesniewicz@awf.wroc.pl \\ 2 Faculty of Life Sciences, University of Silesia in Katowice, ul. Będzińska 60, 41-200 Sosnowiec, Poland \\ 3 Faculty of Finance and Management, WSB University in Wrocław, ul. Fabryczna 29-31, 53-609 Wrocław, \\ Poland; jmarkiewicz@op.pl \\ 4 Faculty of Organization and Management, Silesian University of Technology, ul. Roosevelta 26, \\ 41-800 Zabrze, Poland; innowator@o2.pl \\ 5 Technical University of Liberec, Faculty of Mechanical Engineering, Department of Applied Mechanics \\ Studentská 2, 46117 Liberec, Czech Republic; sona.jandova@tul.cz \\ * Correspondence: slawomir.pytel@us.edu.pl; Tel.: +48-323-689-213
}

Received: 30 January 2020; Accepted: 27 March 2020; Published: 30 March 2020

\begin{abstract}
This paper aimed to present a model of natural environment management in national parks in Poland in the context of increased tourist traffic. The research area comprised Polish national parks as they are characterized by barely altered nature, little human impact, and undisturbed natural phenomena. The methods involved the observational method, literature analysis and criticism, and the in-depth interview method employed in November 2019. The respondents included national park management staff. The questions were prepared in accordance with the Berlin Declaration principles of sustainable tourism development and were extended with the authors' own items. The questionnaire contained 17 questions, grouped in four parts: science and documentation; tourism; cooperation and education; environmental threats. The results indicate that in order for actions to prove efficient in a park, a conservation plan should be carefully developed. Its correctness requires monitoring the state of the environment, tourist traffic size and trends, and tourists' impact on the environment. An important condition for effective tourism management in parks is to increase the competences of the administering bodies and knowledge regarding individuals' responsibilities. Boards should be able to evaluate and modify conservation plans, spatial development plans, municipality development strategies, and projects for investments within the parks.
\end{abstract}

Keywords: sustainability; national park; management; tourism

\section{Introduction}

One of the basic contemporary problems is to maintain balance between tourism development and the need to preserve the valuable natural heritage. The only way to achieve the compromise is sustainable development, the principles of which are embedded in the strategies of all fields of the economy, including tourism. However, the low social awareness of threats, as well as the incomes from tourism for the inhabitants of regions attractive to tourists, significantly complicates the management of valuable natural areas.

The best known form of nature conservation, embracing areas of the most valuable nature and landscape, are national parks. Their idea dates back to the second half of the 19th century, when the first 
national park in the world, Yellowstone National Park, was established in 1872. Some researchers claim that this form of nature conservation should actually be treated as an investment for future generations [1]. Therefore, proper management of a national park is important and should consist in proper planning, organizing, supervising, and controlling its activities [2]. Modern tourism is often oriented towards short-term income and thus contributes to the destruction of what it was originally supposed to profit from. This is caused by excessive concentration of tourist traffic, an improperly located tourist base, often in places of highest natural value, inappropriate forms of organizing recreation, and a lack of tourist culture. The introduction of pro-environmental measures in tourism may contribute to increasing the number of new jobs, while reducing the consumption of non-renewable resources. Planning actions for the sustainable development of human-nature systems requires integrated management and thinking. Two important elements in the management of the relationship between nature and the community are ecosystem services and community livelihoods [3]. Natural protected areas face the challenge of reconciling natural attractions with the satisfaction of different stakeholders without compromising their own resources. Appropriate management and marketing can play an important role in sustainable activities [4]. In terms of management, natural beauty can be a double-edged sword for a given area. Beautiful scenery is a magnet that attracts not only visitors but also second home owners. The latter can make a significant contribution to the local economy; a high demand for moving can increase the prices of local products and real assets, which in turn may affect the quality of life of local residents. On the other hand, the development of real assets may threaten the integrity of natural resources in the area. Therefore, a sustainable approach should be adopted in regions attractive in terms of their natural environment to prevent overtourism [5].

According to the World Commission on Protected Areas, the management of protected areas is now understood as the main element of the legal, political, institutional, and practical framework of conservation worldwide. The concept and its application remain a challenge for most countries. Countries are obliged to promote management diversity and to strengthen the relevant policies, practices, and capacities. The World Commission on Protected Areas (WCPA) has also prepared technical tools, such as the best practice guidelines for the management of protected areas. The Commission's objective is to increase the capacity, effectiveness, and efficiency of protected area managers, both decision makers and others, in relation to sustainable tourism, by learning, exchanging, and developing information and guidance. The presented article is an attempt to engage in the recommendations of the World Commission on Protected Areas.

According to Myga-Piatek and Jankowski [6], tourism is becoming a global social phenomenon, with a considerable anthropogenic impact on the environment. The development of mass commercial tourism, its penetration into all types of landscape, and its impact on various geosystem components are beginning to cause losses and destruction in natural systems, as well as modifications to the socio-cultural environment. The most radical transformations are observed in mountain ecosystems owing to, among others, year-round tourist traffic loads and the orographic specificity. Krupa [7] indicates that the process of tourism management should be holistic, which means that tourism development must be integrated with the development of other economic areas in the region or country. Managing the development of all forms of sustainable tourism, especially in areas of high environmental value, is to consist mainly in properly controlling tourist traffic in time and space, creating zones for different types of tourist penetration, and planning the necessary infrastructure adapted to the individual conditions of the protected area.

On the basis of the above, it was established that it was essential to create a model of natural environment management in national parks in Poland in the context of increased tourist traffic. This became the purpose of the presented paper.

There are many instruments of environmental management in Poland. As indicated by Mizgajski [8], management can be divided into ongoing and programmed environmental protection. The most important groups of current control instruments include legal and administrative procedures and solutions, financial and economic instruments, and sanctions. In the first group, the author enumerates administrative decisions of regulatory nature, administrative proceedings conducted 
with public participation. The financial and economic instruments of environmental management involve, among others, charges for the use of the environment and administrative financial penalties, together with a mechanism for deferring and remitting them when investments are carried out, which eliminate exceeding the permissible levels of pollutant emissions, as well as public funding support for environmental conservation projects. There are also so-called soft instruments related to the market-based approach to environmental conservation by promoting environmentally friendly products. Mizgajski [8] also discusses the second vast sphere of environmental management, namely environmental conservation planning. It covers the whole range of issues related to preparing and evaluating programme documents, including those of a strategic character. All of them must begin with an environmental diagnosis involving an assessment of the state of the environment, anthropogenic impact, as well as the corrective actions taken. On its basis, future changes are projected and the scope of the programme implementation is defined.

However, the literature lacks descriptions of sustainable and comprehensive management. Therefore, it is justified to address the issue of model natural environment management in a sustainable manner, which can be completed by effective, sustainable, and comprehensive management.

\section{Literature Review}

Investigating the relationship between the natural environment and man is of interest to many scientific disciplines. In addition to the biological and geographical sciences that traditionally refer to it, the following should be mentioned: sociology, economics, spatial planning, landscape architecture, urban planning, political science, and law sciences. The scientific discourse is conducted on the basis of the assumptions of the sustainable development concept around the relationships among natural, cultural, and socio-economic values. Such a wide range of research into the relationship between nature and man has yielded a rich literature output.

Human-environment relations are an important research issue of physical and socio-economic geography and regional geography. Here, one can point at works on research methods and relationships between man and nature [9-12]. Moreover, the impact of the park and social dilemmas have been analysed [13-16], as well as major problems and trends in the relationship between the environment and man $[17,18]$. Regional geography has been discussed as a discipline and subject of research and teaching [19-23]. Human activity changes our natural environment and, in extreme cases, even leads to the exhaustion of biodiversity. Chemini and Rizzoli [24] have paid special attention to this, pointing out that biodiversity not only has ethical and cultural value but also plays a role in the functioning of ecosystems.

There is also a wealth of theoretical output in the field of research methods and the assessment of the human-environment relationship. A research methodology has been described [25-28], and modelling sustainable development by constructing theories and typologies has been dealt with [29-32]. Butler [33] reviewed the term 'sustainable tourism,' starting with a discussion on the confusion arising from imprecise and contradictory definitions of the concept and the need to distinguish between sustainable tourism and tourism development based on sustainable development principles.

Numerous studies have focused on quantitative methods and emphasized the economic aspects. The economic benefits of national parks were described [34,35], as well as park management and the costs and advantages of parks. Abel and Blaikie [36] present new ideas for wildlife conservation in Africa, indicating that they are inappropriate. A high proportion of the ideas do not address problems related to social conflicts. It is precisely these historical conflicts that can reveal much about the sources of contemporary ecological problems. The case study of the Luangwa Valley in Zambia demonstrates a method to remedy these weaknesses. In the first part of the article, the authors examine the role of Luangwa national parks in the context of the Zambian political economy and identify social groups competing for park resources. They then follow the historical origins of contemporary ecological changes. These analyses lead to a model of parks and their relationships with the national economy. Clough and Meister [37] point out that since resources are limited, there is greater pressure on those 
who manage them to share them in a way allowing to maximise the benefits to the society. In this study, an attempt was made to do this for the Whakapapa ski field and a village in Tongariro National Park. The aim of the research was to provide information that would allow us to estimate the economic value of the Whakapapa ski field, both for the region and for the whole country. This entails the use of appropriate economic techniques which, although well known abroad, had been relatively rarely used in New Zealand. Trakolis [38] presented the local residents' perception of planning and management issues, as investigated in a national park in north-western Greece. The conflicts caused by the lack of the local community participation in the designation procedure and then in the decision-making process required research. The author verified the knowledge about the park and its objectives, the necessity of works and the quality of infrastructure, attitudes towards certain decisions, and the management pattern and effectiveness. Ferraro [39] focused on the fact that the long-term integrity of protected areas in low-income countries depended on the support of the neighbouring rural communities. He pointed out the need to understand the alternative costs of nature conservation, which are borne by the rural communities neighbouring the protected areas. The author stated that there were few analyses of the effects of establishing protected areas. Cihar and Stankova [40] collected opinions and attitudes towards nature conservation and tourism in the territory of a Czech national park that had been closed to the public for 40 years because of the Iron Curtain. The authors conducted a survey among visitors, residents, and representatives of local self-governments.

An important issue raised in the literature was the awareness of the need to involve local communities in the processes of managing natural resources and protected areas. The researchers pointed out that the condition of the coexistence of nature and people living in protected areas was proper social communication.

Another issue was the impact of the community on national parks. Jarvis [41] points out that land protection in parks is often perceived as a cost for the economic development of rural areas. However, the debate on the development of the Canyon Forest Village on the southern edge of the Grand Canyon suggested the opposite. It indicated that natural systems could be extremely valuable to rural economies and that national parks and rural area development could go hand in hand. According to Kideghesho et al. [42], attitude research is increasingly recognized as a tool for assessing public understanding and acceptance for protection. The results of the study were useful in guiding political interventions. The investigators found that attitudes were positively or negatively influenced by many factors. Factors triggering positive attitudes reinforce protection objectives, while those generating negative attitudes may adversely affect the objectives.

There is also research on social conflicts in national parks. Fortin and Gagnon [43] indicate that many national parks have been established around the world to protect nature, but not without consequences for the neighbouring communities. As the social and economic development of the population living around the park is increasingly recognized as essential to achieve protection objectives, the quality of park-community relationships has become a key issue. Burger [44] emphasizes the importance of the position of local people in the case of investments that may affect their lives. He claims that the participation of the local community in the course of park construction should be a significant element of the decision-making process. Królikowska [45], points to the so-called British concept of the relationship between the local population and the protected area, where people are perceived as an integral part of the landscape. The system of managing protected areas is as a rule focused more on sustainable development than on strict protection. This approach allows for the promotion of agricultural, forestry, or fishing activities within protected areas. Hibszer [46] referred to a key issue of the relationship between man and environment. The problem addressed in the study concerned the relationship between the national park and the local community. Its essence was to answer the question of how the population living in national parks or their vicinity perceived their relationship with their closest national park. The awareness of the need to maintain balance between the protection of natural and landscape values and the social and economic development of park communes, as declared by the authorities, is an important premise for verifying the relationships between this form 
of protected areas and local communities in Poland. According to Barker [47], further development of mass tourism in the Alps burdens the landscape and the local communities. However, various forms of the development are observed. In the western Alps, ski resorts develop at high altitudes, outside local communities. In the eastern Alps, tourist facilities are concentrated around traditional communities. Congestion and pollution are obvious. Local and regional planning strategies adopted in response to changes in tourism in the Alps provide relevant experiences for other mountain regions.

Other social conflicts have also been described. Beltran [16], presented an interesting way of resolving conflicts between a national park and the population on the example of Sagarmatha National Park. The government of Nepal responded to international concerns about the environmental crisis by establishing Sagarmatha National Park. In many parts of the world, the formation of national parks displaced indigenous people and imposed a strict nature conservation policy to create 'wilderness'. Sagarmatha National Park, on the other hand, was a pioneering example of a new type of protected area, which recognized the rights of indigenous people to settle and provide for themselves. Bauer [48], on the example of Waza National Park in Cameron, indicated complex interactions between the park and the surrounding population. The adopted management plan allowed for human cooperation, with a limited use of natural resources. In order to determine which resources were desirable and which represented commitments, interviews were conducted with people from the park vicinity. In their study, Bojórquez-Tapia et al. [49] recognize nature reserves as a category of land use that competes with other land uses. Therefore, one of the basic objectives of conservation planning is to design reserves that protect the most valuable areas. However, the complexity of conservation issues, as well as the urgent need to protect the key elements of biodiversity and a lack of data, forced planners to rely on expertise and public participation when developing projects. According to Colchester [50], nature protection through establishing 'national parks' in the USA violated the rights of indigenous people, causing their impoverishment and social problems. After many efforts, international rules finally acknowledge the rights of indigenous people, and the new protection policy allows them to own and manage protected areas. Nevertheless, field studies show that these new rules are not yet widely applied. Stern [51] presents a model based on empirical research explaining local objections to neighbouring protected areas. Analyses of data from 420 interviews with local residents and almost a year's observation of three national parks revealed that the assumptions concerning local residents motivated primarily by rational economic stimuli were at best incomplete.

Some research pointed at ways to resolve conflicts through appropriate resource management [52-55].

The tourist traffic in national parks has also been studied and described on numerous occasions. Many studies have been devoted to the sustainable development of tourism [56-60]. Debates on sustainable tourism were conducted, among others, by Hunter [61]. Paunović and Jovanović [62] tried to answer the question of what lay behind the efforts for sustainable tourism in the German Alps and what views on these processes were represented by various stakeholders in the tourism industry.

The issue of modern tourism business in local development was discussed by Mortensen et al. [63] and Mika [64]. Elmi and Perlik [65] decided to investigate the reappearance of residents in the Alps. Research carried out in previous years highlighted the depopulation of these areas, and now the authors have observed the phenomenon of a renewed influx of inhabitants. There are also theoretical references to the man-nature tourism impacts [66-69]. The benefits of tourism for natural resource management in parks have been described [70-75]. Gios et al. [76] measured the benefits of natural resources for tourism. They pointed out that measuring certain advantages made it possible to create appropriate development strategies. The researchers presented possible solutions for sustainable tourism in environmentally valuable areas.

Among the investigations on the attitude of local communities to national parks, the studies of many researchers stand out. They point to the objection of local communities to delimiting protected areas. Kaltenborn et al. [77] indicated that the community-based management of protected areas had become a strong political objective worldwide. Many African countries responded to this challenge, although with variable results. Tanzania, known for its abundant wildlife population in national parks, 
developed several projects aimed at improving the relationship between the park and people. So far, however, there is little evidence that community-based programs have had any significant impact on management strategies, benefit distribution, or poverty alleviation. Von Ruschkowski [78] claims that the designation of protected areas (e.g., national parks) often leads to conflicts between local communities and the area administration. This phenomenon occurs all over the world and is probably as old as the very idea of a national park. These conflicts often affect both the protected areas and the local communities, as tense relationships entail the risk of disruption to park planning, conservation objectives, or regional economic development.

Researchers also determine the factors influencing acceptance. Raval [79] discussed investigations carried out to understand resource use and management issues, as perceived by the people living in the park vicinity. The study was conducted in the form of in-depth interviews, mainly with cattle breeders living in Gir National Park in India. Fiallo and Jacobson [80] pointed out that the economic and social problems faced by many developing countries threatened the existence of such parks. Similarly, other authors [81-83].

\subsection{Sustainable Development}

According to Piontek [84], more than 40 definitions of sustainable development are mentioned in the literature. They all draw attention to the different manifestations of the use, application, and understanding of these words. The notion of sustainable development was first publicly applied during the first United Nations Conference on Environment and Development in Stockholm in 1972. The first definition, in turn, appeared at the United Nations Environment Programme management body session in 1975 and described sustainable development as a course of inevitable and desirable economic development that did not significantly or irreversibly disturb the human environment, did not lead to biosphere degradation, and reconciled the laws of nature, economics, and culture. For the purposes of this study, the definition of sustainable development was adopted as the right to satisfy the development aspirations of the current generation without limiting the rights of future generations to satisfy their development needs [85]. This definition indicates that sustainable development does not constitute environmental conservation in its conventional meaning. Through the harmony of economic, natural, and social aspects, this development is safe and beneficial for man, the environment, and the economy. It does not hinder development but even stimulates it, it does not take place at the cost of destroying the environment, for the benefit of future generations, who will also have the right to develop. Weaver, D.B., and Lawton, L.J. [86] identify a deepening crisis of protected areas, which is affected by four factors. Firstly, relatively undisturbed natural habitats around the world continue to be destroyed and converted to serve other purposes as human populations increase, prosperity develops, and more natural resources are used. Secondly, the reduced government funding worldwide decreases their ability to fulfil key environmental functions. Thirdly, revenues are visitor-based and, as a result, a large part of them is spent on visitor satisfaction and not on environmental management. The fourth factor is the increasing demand for rural outdoor and nature-based recreation in the increasingly urbanized societies.

Leung, Y.F. [87] points out that protected area managers need a wide range of skills and expertise to manage the complexity of protected area systems. The IUCN best practice guidelines are designed to meet these needs, including the sharing of good practice experience around the world. Many protected areas are managed for tourism and visits as part of their objective, involving a wide range of stakeholders and the private sector. The rapidly growing demand for the development of tourism related to protected areas emphasizes the need to provide clear guidance that will contribute to sustainable tourism in line with the fundamental objectives of protecting valuable areas. From a conservation point of view, tourism and sightseeing represent a complex set of challenges. Protected area managers around the world are expected to make most of the areas accessible to visitors. Protected areas are a crucial element of any global conservation strategy. Tourism acts as an important way of connecting visitors and valuable protected areas. 
Eagles, P.F., Bowman, M.E., and Tao, C.H. [88] elaborated on the ideas discussed above primarily for the planners and managers of parks and protected areas. It was designed to help park managers think about the inflow of tourists into protected areas and to encourage them to consciously plan the management of the interaction between tourists and the environment. Effective planning allows different interest groups to maximize the potential positive effects of tourism while minimizing the negative ones. The document is an important and requested material for protected tourism in East Asia. It constitutes a valuable resource for park managers and other decision makers involved in park planning, supplementing current practices and theories applied by park authorities. The document contains information on best practices, guest management, education, stakeholder involvement, and other issues related to the protected area.

Mandić, A. [89] indicates that protected natural areas are often considered as areas of high recreational value; therefore, many of them are increasingly threatened by the development of tourism. The research was conducted in a socio-economic context to address the complexity of this global problem. The study is based on an inductive approach to highlight the need for eco-thinking. The paper provides an analysis of global and local factors that drive change. It concludes that the durability of nature-based tourism and the resilience of protected areas are not possible in the absence of a multi-level management system, monitoring, education, and community consent.

Mandić, A., and Petrić, L. [90] presented a study that analysed the economic effects of creating protected areas and indicated the implications for the public and private sectors. To this end, they applied the hedonic pricing method in order to take into account changes in hotel prices in relation to their location. The research results revealed a relationship between the unique environmental attributes of a site and hotel prices. Hotels located near the territory of a national park charge higher fees, while increasing the distance from the park territory reduces prices. The researchers found that protected areas were components of an integrated tourist product, influencing the prices of complementary tourist services, visitors' satisfaction, and the competitiveness of destinations.

\subsection{Tourism in the Aspect of Sustainable Development}

New needs and expectations of tourists are the basis for creating tourist products that are consistent with the principles of sustainable development. These principles are so crucial that the concept of sustainable tourism has developed, as defined in the Charter for Sustainable Tourism. The concept is the result of seeking dependencies and links between the economic, environmental, and social factors determining development with a balance among them [91]. Any attempt to introduce the concept of sustainable tourism development involves the need to relate it to a specific area with a specific tourism potential. In this case, these are national parks, where the values of the natural environment, the existing development, as well as tourist traffic and its consequences must be studied. This leads to a concept of sustainable tourism management in the region. Gałazka [91] implies that, in accordance with the definition presented by the European Federation of Natural and National Parks, sustainable tourism should be considered to be any form of development of tourist traffic, tourist activity, and management that maintains the ecological, social, and economic integrity of territories and preserves their natural and cultural resources for future generations. According to Para [92], the definition of sustainable tourism should acknowledge the environmental durability, relate to the economy concerned, and be socially and ethically adapted to the standards of the given community. These conditions can be met if all parties involved in tourism respect one another and cooperate. Sustainable tourism has been addressed by many researchers, who presented the understanding of and challenges for sustainable tourism development and the roles of stakeholders [93-96], as well as the problems of tourist indicators, sustainable development, environmental management, and measuring satisfaction with sustainable tourism [97-99]. An important role of research into new ways of describing sustainable tourism has been explored by McCool, S.F., and Bosak, K. (Eds.) [100]. Their investigation indicated that tourism is only one of many human activities that affects host communities. Their paper includes engaging case studies with realistic applications. The references contained in the book, as well as 
tools and techniques useful for tourism practitioners, suggest an innovative approach to marketing, management, and community development. The authors point out that sustainable development is becoming a top priority, as tourist destinations try to maintain and increase their attractiveness to tourists. However, tourism is now an economic activity and an engine of global capitalism. For this reason, there is a tension between tourism and sustainable development. The researchers conduct an important discussion on how sustainable tourism can be reformulated with the use of the indicated set of tools.

\subsection{The Essence of National Park Management}

Environmental management is mainly the management of conservation and environment formation. It is based on the so-called Deming circle, in which the actions taken are grouped into planning, implementing the plan, checking (assessing the effectiveness of the actions), correcting shortcomings, and adapting the plan to the new circumstances. Therefore, the system of environmental management is grounded in cyclical activities aimed at continuous improvement [101].

As indicated in Article 8b Item 1 of the act on nature conservation [102], the responsibilities of national parks include in particular:

1. Carrying out conservation activities in the national park ecosystems, aimed at achieving the objectives referred to in Article 8 Item 2;

2. Providing access to the national park area in accordance with the principles set out in the conservation plan referred to in Article 18 or in the conservation responsibilities referred to in Article 22 and in the ordinances of the national park director;

3. Conducting activities related to nature education.

The management of a national park should be performed in at least three categories:

- The management of nature conservation;

- The management of a business entity;

- The management of a public institution.

Nature conservation and the negative effects of tourist traffic in national parks are enumerated both in the act on nature conservation [102] and in the ordinances of the national park director. In order to counteract these effects, the national park director determines, among others, the number of people who can stay in a given place at the same time or the amount of admission fees. An important role is also ascribed to conducting educational activity, aimed primarily at teaching the society how to use natural resources [100].

National parks are also business entities. Kunasz [103] specifies that the resources of national parks include:

- Tangible resources, such as natural resources, land, buildings, means of transport, machinery, and equipment;

- Human and organizational resources: national parks have their own organizational structures;

- Financial resources, understood as the possibility of obtaining the income characteristic of national parks, including special purpose grants, revenues related to providing access to the national park, and conducting educational activity, as well as income from timber sales.

National parks cannot be managed by economic instruments alone. These may only be used to supplement administrative and legal instruments. That is why the organizational and legal status of the park plays an important role in its management. As indicated by Ruśkowski and Salachna [104], a national park is a state legal entity; therefore, it can be a subject of civil law relations and can take credits and loans (up to $60 \%$ of the amount of income or $60 \%$ of costs), and the property of a national park entirely constitutes state property. In turn, the Act on public finance [105] in Article 9 Item 14 specifies that a national park is a public finance sector unit, managed by the park director, 
but supervised by the Minister of Environment. And it is the Minister of Environment who controls the operation of national parks.

Wasiuk [100] presented two main factors in national park management:

1. The factor distinguishing a national park from other entities: the legal regulations governing the activities of national parks, the management of a particular type of resources in national parks, and the dependence of the decisions taken on the needs of nature;

2. The factor differentiating national parks: the attractiveness of the national park for visitors, the significance of the park's nature for the society, the location and size of the park and its assets, budget size (including the amount of state funding and of so-called own revenues), and the number of employees.

The European Charter for Sustainable Tourism provides an important management model. It is an initiative of EUROPARC, which has long recognized the need to care for both the land and the people who live and work there. National parks are not only facing challenges and pressures arising from the visits to and misuse of the land that they manage; they also have the opportunity and potential to act as catalysts for change in sustainable development and lifestyle at the local, regional, and even national level. The European Charter for Sustainable Tourism in Protected Areas is a practical management tool that enables sustainable tourism development in protected areas. A key element of the charter is a common strategy for sustainable tourism and an action plan based on an in-depth analysis of the situation. The aim of all projects and actions of the charter is to protect the natural and cultural heritage and to continuously improve tourism in protected areas in terms of the environment, local people, and businesses, as well as visitors. Over 20 years of experience have shown that the charter is a useful and important tool that provides social, environmental, and economic benefits.

\section{Material and Methods}

The research involved 23 national parks owing to the prominence of the natural heritage that they have and make available to tourists. National parks are a sanctuary of wildlife, a place where protection is provided for entire ecosystems, i.e., all living organisms linked by interrelationships and inanimate elements of the environment in which they exist.

For this reason, the management of a national park is extremely difficult and requires model solutions to protect what is most valuable and at the same time to make it available to tourists.

\subsection{Research Area}

The research area comprised Polish national parks as they are characterized by barely altered nature, little human impact, and undisturbed natural processes and phenomena. Here, there is the last natural forest of the European Plain, the location of many unique and endangered species of fauna and flora, and the most famous bison habitat in the world.

In Poland, 23 national parks were created (Figure 1), which cover $1 \%$ of the country area. The parks operate on the basis of the act of April 16, 2004, on nature conservation. In accordance with Article 8 Item 1 of the act, a national park covers an area distinguished by specific natural, scientific, social, cultural, and educational values, with an area of not less than 1000 ha, where all nature and landscape values are subject to conservation. The internal organization, mode of operation, and manner of granting powers of attorney have been modified; since January 1, 2012, there is a regulation in force according to which the minister in charge of the environment, by way of an ordinance, grants a national park its statute, considering the need to ensure its efficient operation. A national park is managed by a director, appointed by the Minister of Environment, for a period of five years, from among the candidates selected by a competition. 


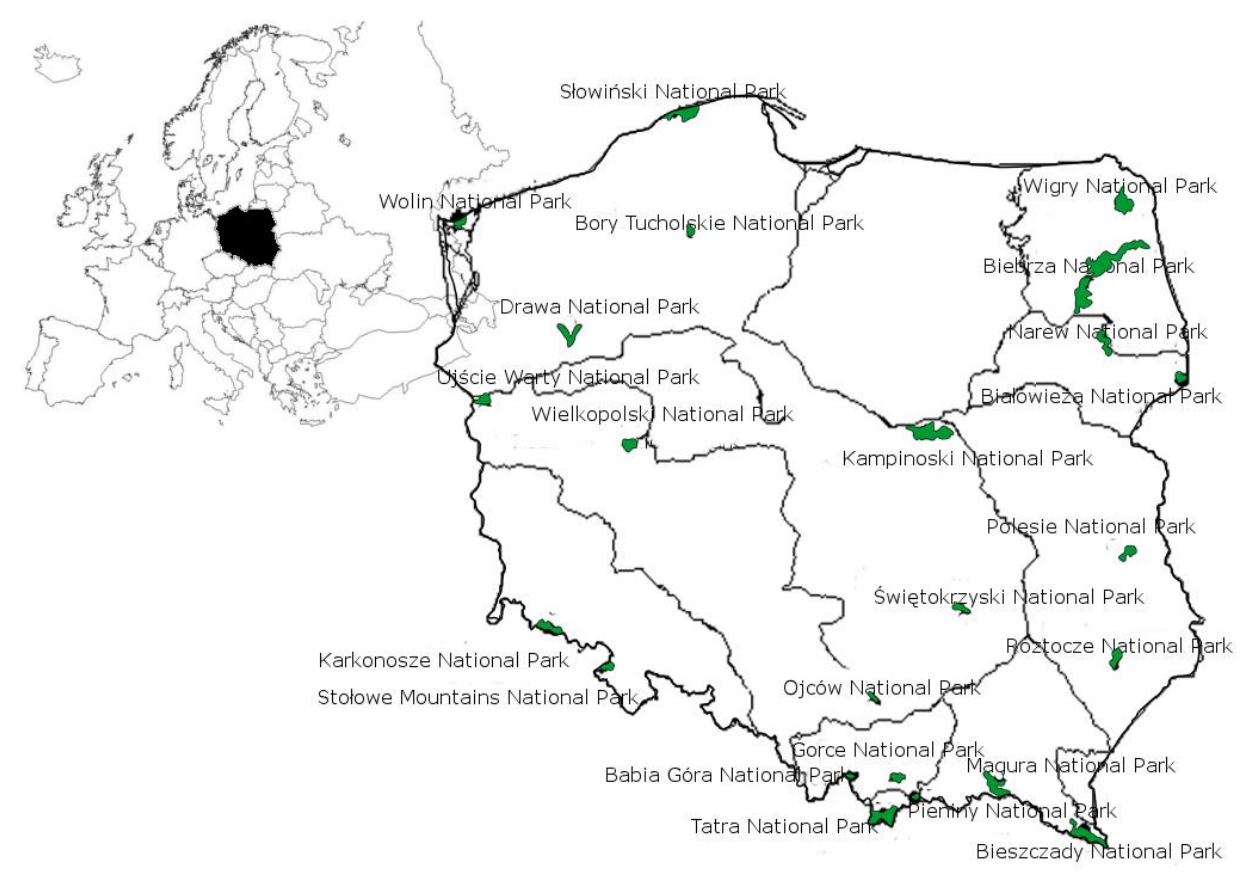

Figure 1. National parks in Poland against the background of Europe [106].

An important feature of the tourist traffic in national parks is the seasonality of visits, limiting the tourist traffic peak to 2-3 months. In most national parks, the tourist traffic is seasonal in nature, and the dependence on this factor has different significance in individual parks. Coast parks are burdened with a large number of visitors only during the holiday period. Mountain parks, where winter tourism is also practised, have more balanced numbers of visits. The number of days off from work (the so-called long weekends) also affects the increase in the number of park visitors: there are more individual trips and several-hour visits with own transport.

\subsection{Research Methods}

In the paper, the following research methods were used: the observational method, the method of analysis and criticism of literature, and the method of in-depth interviews. The observation method played a major role. Observation is among the oldest research methods, allowing to put forward a hypothesis, collect data, verify and select materials, clarify issues, formulate a thesis, establish contacts with the studied group. Its characteristic feature is cyclicality. Observation as a method must assume a selection of observations under predefined conditions. It must adopt an appropriate selection, the criterion being determined by the purpose of the observation. Observation is a research method when it considers all stages of research activities. As a method, it determines how to prepare and implement the research technique and tools, consolidate observations, compile observation protocols, and develop research results and scientific generalizations. The most characteristic feature of observation is its cyclic nature: it starts with facts and ends with them, and the facts ending one cycle begin the subsequent one [94].

Another method was that of literature analysis and criticism. With this method, one can determine what is known and what is not known, and what exists in the literature and what is not there yet. One can establish whether the problem addressed is original, different from the discoveries known so far. The method allows to demonstrate differences, similarities, relationships, dependencies, and substantial features in the existing theories. The results of studies based on this method lead to important discoveries concerning activities and creative works. This method is widely used in humanities but also in economic sciences. Its aim is also to establish relationships between products of creative activity. It is usually about determining the impact of one solution on another, for example, 
one work on another, one theory on another. Since comparison is among the basic mental activities, it is an important component of most research methods [94].

An important role was played by the in-depth interview method. It consists in a conversation between a researcher and a respondent. The objective is to obtain detailed opinions and information from specific individuals who meet the sampling criteria defined by the investigator. The technique is also applied to explain the nature of the phenomenon under investigation, to get to the essence, and to obtain information that would be difficult to achieve with other methods. In a regular questionnaire, the respondent is usually confronted with a list of available answers to questions. In an in-depth interview, the emphasis is on freedom of expression. The interviewer directs the conversation in such a way that all topics are covered, but allows full freedom of expression on the part of the respondent. For this reason, the interview usually takes about 1 hour. In-depth interviews should be chosen when one wants to get to know the independent opinions of experts, discover the opinions of hardly accessible people, raise difficult issues. In-depth interviews allow us to well understand the opinions and attitudes of the interlocutors, describe the motives of actions, check the level of comprehension of ideas and materials, explore a brand image, determine the characteristics of a potential user, describe attitudes towards social phenomena, and determine the optimal level of changes proposed in the environment [94].

The research was conducted in November 2019 and followed the steps presented in Figure 2.

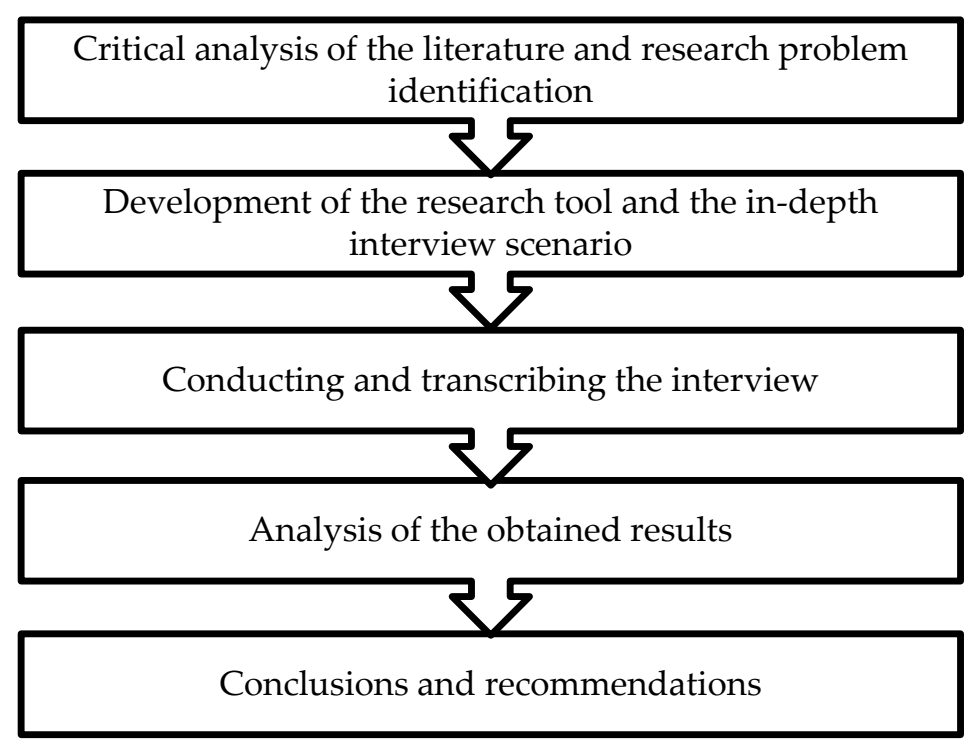

Figure 2. The study flowchart (source: own research).

In the initial phase, the authors gathered numerous literature references and, after exploring them, identified the research problem. The proposed problem was to provide strategic advice to the authorities of protected areas, the tourism industry, and other stakeholders on an optimal approach to planning, developing, managing, and monitoring tourism in protected areas. Further on, in accordance with the Berlin Declaration [107], the authors developed a research tool in the form of a questionnaire, which contained 17 questions and consisted of four parts. The next step was research conduction. For this purpose, all national parks in Poland were contacted and the management staff represented by directors, their deputies, or indicated persons were interviewed. After the results were obtained, their statistical processing was started, which consisted of elaborating the primary data into an acceptance index. In the last part, the authors analysed the obtained results and drew conclusions.

The respondents included national park management staff, such as directors, their deputies, or heads of departments. The questions were prepared in accordance with the Berlin Declaration [107] principles of sustainable tourism development and were extended with authors' own items. 
The questionnaire contained 17 questions and consisted of four parts: science and documentation, tourism, cooperation and education, and environmental threats.

The statistical analysis consisted in processing the obtained primary data into an acceptance index (AI) ranging from 0 to 1 , where 1 indicated full conformity with the analysed requirements. The answers were analysed with reference to all parks together and with the consideration of a distinction into two criteria. The first one was the park qualification as a United Nations Educational, Scientific and Cultural Organization (UNESCO) biosphere reserve or not, the other one constituted a division into five groups resulting from the park type (coast, lake district, lowland, upland, and mountain).

The national park managers were asked the following questions:

1. Does the park have a nature conservation plan?

2. Are environmentally friendly forms of tourist activity promoted?

3. Are there any limits on the number of visitors and people walking on the trails?

4. Are there any specified places where one can put up a tent?

5. Has tourism been identified as an existing or potential threat to the nature of the park?

6. Are environmental indicators for sustainable tourism planning taken into account?

7. Is the development of tourism restricted in areas that have been under greatest impact so far?

8. Is there a monitoring of the existing tourist traffic?

9. Is the environmental impact of tourism monitored?

10. Have the changes in the environmental impact of tourism development been assessed before?

11. Is the existing tourist infrastructure being modernized instead of building a new one?

12. Is ecological education run?

13. Have educational pathways been established?

14. Is there cooperation with local government units?

15. Have regulations been developed concerning the specific way of making the park available?

16. Is admission fee income received?

17. Does the director have a scientific council?

On the basis of a broad source base, an analysis of the current development of tourism in parks and plans in this respect was made. The Local Data Bank of Statistics Poland [108] and websites of parks and tourist organizations served to establish the number of park visitors. As a measure of tourist traffic in national parks, the indicator of tourist traffic intensity was applied, which is the quotient of the number of tourists (thousands) and the length of tourist trails (kilometres). The study also employed the Defert index, providing information on the number of tourists per $1 \mathrm{~km}^{2}$ of a tourist area, which allows one to assess the population density in the studied area $[109,110]$.

\section{Results}

\subsection{Results of Secondary Sources Research}

The main measure of the tourist function of a given area is the tourist traffic, defined as the movement of people for tourist purposes in the area. More than half of the total tourist traffic in Poland is generated by mountain parks; however, most of the tourist traffic is seasonal in nature. The exceptions are mountain parks, such as Karkonosze National Park and Tatra National Park, where winter tourism is also practised. Polish national parks are very popular among tourists, as evidenced by their high attendance. The creation of each new national park is associated with an influx of tourists. In the first half of the 1960s, when there were only 10 national parks in Poland, the number of visitors was between 4 and over 5 million per year, with a clear tendency to increase. Such high attendance involved company visits, school excursions, and individual tourism. In the 1970s, the number of visitors increased to over 11 million per year. At present, the attendance of visitors to particular national parks varies from 13 thousand people in Drawa National Park to over 3.7 million in Tatra National Park. 
In nine parks, the annual number of tourists does not exceed 100 thousand (Table 1). In the following seven, it does not exceed 1 million. The attendance exceeded 1 million in only five parks.

Table 1. Number of tourists visiting Polish national parks in 2009-2017.

\begin{tabular}{lcccccccccc}
\hline \multirow{2}{*}{ Park Name } & \multicolumn{7}{l}{ Number of Tourists (in thousands) } & & & \\
\cline { 2 - 10 } & $\mathbf{2 0 0 9}$ & $\mathbf{2 0 1 0}$ & $\mathbf{2 0 1 1}$ & $\mathbf{2 0 1 2}$ & $\mathbf{2 0 1 3}$ & $\mathbf{2 0 1 4}$ & $\mathbf{2 0 1 5}$ & $\mathbf{2 0 1 6}$ & $\mathbf{2 0 1 7}$ \\
\hline Tatra National Park & 2195 & 2002 & 2234 & 2947 & 2764 & 3092 & 3310 & 3683 & 3779 \\
Karkonosze National Park & 2000 & 2000 & 2000 & 2000 & 2000 & 2000 & 2000 & 2000 & 2000 \\
Wolin National Park & 1500 & 1500 & 1500 & 1500 & 1500 & 1500 & 1500 & 1500 & 1500 \\
Wielkopolski National Park & 1200 & 1200 & 1200 & 1200 & 1200 & 1200 & 1200 & 1200 & 1200 \\
Kampinoski National Park & 1000 & 1000 & 1000 & 1000 & 1000 & 1000 & 1000 & 1000 & 1000 \\
Pieniny National Park & 838 & 603 & 710 & 770 & 734 & 719 & 815 & 931 & 898 \\
Stołowe Mountains National Park & 366 & 319 & 335 & 350 & 347 & 367 & 480 & 286 & 515 \\
Bieszczady National Park & 350 & 280 & 330 & 297 & 332 & 355 & 388 & 487 & 513 \\
Ojców National Park & 400 & 400 & 400 & 400 & 400 & 400 & 400 & 428 & 430 \\
Słowiński National Park & 386 & 311 & 317 & 312 & 309 & 304 & 319 & 323 & 317 \\
Białowieża National Park & 190 & 170 & 134 & 121 & 119 & 120 & 133 & 163 & 249 \\
Roztocze National Park & 100 & 100 & 100 & 120 & 120 & 120 & 134 & 187 & 203 \\
Świettokrzyski National Park & 183 & 145 & 193 & 162 & 148 & 135 & 132 & 144 & 144 \\
Wigry National Park & 120 & 110 & 110 & 110 & 110 & 115 & 110 & 125 & 125 \\
Gorce National Park & 70 & 60 & 65 & 70 & 70 & 80 & 80 & 80 & 90 \\
Babia Góra National Park & 67 & 54 & 75 & 63 & 81 & 76 & 81 & 114 & 83 \\
Magura National Park & 50 & 50 & 45 & 40 & 50 & 40 & 40 & 50 & 50 \\
Polesie National Park & 25 & 24 & 24 & 28 & 28 & 28 & 41 & 44 & 49 \\
Biebrza National Park & 39 & 31 & 27 & 33 & 28 & 32 & 39 & 41 & 47 \\
Ujście Warty National Park & 20 & 10 & 20 & 57 & 54 & 51 & 52 & 43 & 34 \\
Bory Tucholskie National Park & 60 & 60 & 60 & 60 & 33 & 33 & 33 & 35 & 32 \\
Narew National Park & 11 & 13 & 10 & 12 & 15 & 15 & 15 & 20 & 19 \\
Drawa National Park & 24 & 22 & 48 & 26 & 19 & 18 & 22 & 16 & 13 \\
\hline
\end{tabular}

Source: own elaboration based on Statistics Poland [108].

Changes in attendance were most marked in Roztocze National Park and Polesie National Park, where the number of visitors increased by 100\% in the examined period of 2009-2017. The most unfavourable situation was observed in Bory Tucholskie National Park and Drawa National Park, where the number decreased by a half (Table 1).

An important role is played by the length of the designated tourist trails, as it determines the possibility of dispersing tourists around the park area and not exerting excessive environmental impact by tourists. The length of trails is significantly varied and ranges between $16.7 \mathrm{~km}$ in Ujście Warty National Park to $550 \mathrm{~km}$ in Kampinoski National Park. There are over $200 \mathrm{~km}$ of trails in seven parks and over $100 \mathrm{~km}$ in five (Table 2).

In order to determine the tourist traffic impact on the nature of the park, in addition to the total number of visitors, it is important to establish their 'density' in the park area and along the tourist trails. Taking into account the number of tourists and the size of the park, one can more precisely estimate the impact and compare the parks.

Excessive concentration of tourist traffic or incorrectly located tourist base, as well as inappropriate forms of recreation management and a lack of tourist culture are the main reasons for threats. The development of tourism in protected areas is therefore highly limited. Any actions taken must be consistent with the principles of sustainable development, and the number of tourists visiting a park should be adjusted to the park area. The calculated Defert index implies that the highest density, 3.7 people per $\mathrm{km}^{2}$, is in Pieniny National Park. Equally high density occurs in Karkonosze National Park. Tourists will find the most space in Biebrza National Park and Narew National Park (Table 3). 
Table 2. Length of tourist trails in Polish national parks in 2009-2017.

\begin{tabular}{|c|c|c|c|c|c|c|c|c|c|}
\hline \multirow{2}{*}{ Park Name } & \multicolumn{9}{|c|}{ Tourist Trails (in kilometres) } \\
\hline & 2009 & 2010 & 2011 & 2012 & 2013 & 2014 & 2015 & 2016 & 2017 \\
\hline Kampinoski National Park & 560 & 560 & 560 & 550 & 550 & 550 & 550 & 550 & 550 \\
\hline Biebrza National Park & 474 & 464 & 464 & 493 & 498 & 498 & 524 & 499 & 499 \\
\hline Bieszczady National Park & 245 & 140 & 465 & 465 & 465 & 465 & 465 & 465 & 465 \\
\hline Tatra National Park & 275 & 275 & 275 & 275 & 275 & 275 & 275 & 275 & 275 \\
\hline Wigry National Park & 245 & 245 & 245 & 245 & 273 & 273 & 273 & 273 & 273 \\
\hline Drawa National Park & 160 & 170 & 164 & 170 & 170 & 241 & 241 & 241 & 241 \\
\hline Wielkopolski National Park & 215 & 215 & 215 & 215 & 215 & 215 & 215 & 215 & 233 \\
\hline Gorce National Park & 155 & 155 & 155 & 155 & 155 & 169 & 169 & 169 & 169 \\
\hline Słowiński National Park & 144 & 144 & 144 & 144 & 144 & 150 & 150 & 166 & 166 \\
\hline Polesie National Park & 76 & 136 & 136 & 136 & 114 & 114 & 114 & 114 & 127 \\
\hline Karkonosze National Park & 118 & 118 & 118 & 118 & 118 & 118 & 118 & 121 & 126 \\
\hline $\begin{array}{l}\text { Stołowe Mountains National } \\
\text { Park }\end{array}$ & 107 & 164 & 196 & 109 & 109 & 109 & 109 & 109 & 109 \\
\hline Magura National Park & 85 & 98 & 85 & 85 & 94 & 94 & 94 & 94 & 94 \\
\hline Bory Tucholskie National Park & 75 & 75 & 76 & 92 & 92 & 93 & 93 & 93 & 93 \\
\hline Babia Góra National Park & 53 & 53 & 55 & 55 & 55 & 55 & 55 & 49 & 55 \\
\hline Narew National Park & 55 & 55 & 55 & 55 & 55 & 55 & 55 & 55 & 54 \\
\hline Wolin National Park & 50 & 50 & 50 & 50 & 50 & 50 & 50 & 50 & 50 \\
\hline Białowieża National Park & 44 & 44 & 42 & 44 & 44 & 44 & 44 & 44 & 44 \\
\hline Świętokrzyski National Park & 41 & 38 & 38 & 38 & 38 & 41 & 41 & 41 & 41 \\
\hline Ojców National Park & 40 & 40 & 40 & 37 & 37 & 37 & 37 & 37 & 37 \\
\hline Pieniny National Park & 35 & 35 & 35 & 35 & 35 & 35 & 35 & 35 & 35 \\
\hline Roztocze National Park & 61 & 31 & 31 & 29 & 29 & 29 & 29 & 29 & 29 \\
\hline Ujście Warty National Park & 13 & 13 & 13 & 13 & 13 & 17 & 17 & 17 & 17 \\
\hline
\end{tabular}

Source: own elaboration based on Statistics Poland [108].

Table 3. Number of tourists visiting Polish national parks in 2009-2017 per $1 \mathrm{~km}^{2}$

\begin{tabular}{|c|c|c|c|c|c|c|c|c|c|}
\hline \multirow{2}{*}{ Park Name } & \multicolumn{9}{|c|}{ Number of Tourists (per $1 \mathrm{~km}^{2}$ ) } \\
\hline & 2009 & 2010 & 2011 & 2012 & 2013 & 2014 & 2015 & 2016 & 2017 \\
\hline Pieniny National Park & 3.570 & 2.570 & 3.030 & 3.246 & 3.090 & 3.030 & 3.440 & 3.930 & 3.790 \\
\hline Karkonosze National Park & 3.580 & 3.580 & 3.580 & 3.584 & 3.580 & 3.580 & 3.580 & 3.360 & 3.360 \\
\hline Ojców National Park & 1.864 & 1.864 & 1.864 & 1.864 & 1.864 & 1.864 & 1.864 & 1.995 & 1.995 \\
\hline Tatra National Park & 1.030 & 0.080 & 1.050 & 1.390 & 1.300 & 1.459 & 1.561 & 1.740 & 1.780 \\
\hline Wielkopolski National Park & 1.582 & 1.582 & 1.580 & 1.582 & 1.580 & 1.580 & 1.580 & 1.580 & 1.580 \\
\hline Wolin National Park & 1.370 & 1.370 & 1.37 & 1.374 & 1.370 & 1.370 & 1.370 & 1.370 & 370 \\
\hline Stołowe Mountains National Park & 0.580 & 0.500 & 0.530 & 0.552 & 0.550 & 0.580 & 0.760 & 0.460 & 0.820 \\
\hline Kampinoski National Park & 0.260 & 0.260 & 0.260 & 0.259 & 0.259 & 0.259 & 0.259 & 0.295 & 0.295 \\
\hline Babia Góra National Park & 0.170 & 0.160 & 0.220 & 0.186 & 0.239 & 0.190 & 0.240 & 0.340 & 0.245 \\
\hline Roztocze National Park & 0.118 & 0.118 & 0.118 & 0.141 & 0.141 & 0.141 & 0.160 & 0.220 & 0.240 \\
\hline Białowieża National Park & 0.180 & 0.170 & 0.127 & 0.115 & 0.110 & 0.110 & 0.129 & 0.156 & 0.237 \\
\hline Świętokrzyski National Park & 0.240 & 0.190 & 0.254 & 0.212 & 0.195 & 0.177 & 0.173 & 0.189 & 0.189 \\
\hline Bieszczady National Park & 0.012 & 0.096 & 0.113 & 0.102 & 0.114 & 0.122 & 0.133 & 0.167 & 0.175 \\
\hline Słowiński National Park & 0.179 & 0.144 & 0.147 & 0.145 & 0.143 & 0.141 & 0.148 & 0.150 & 0.147 \\
\hline Gorce National Park & 0.100 & 0.086 & 0.092 & 0.100 & 0.100 & 0.110 & 0.110 & 0.110 & 0.129 \\
\hline Wigry National Park & 0.080 & 0.073 & 0.073 & 0.073 & 0.073 & 0.076 & 0.073 & 0.083 & 0.083 \\
\hline Bory Tucholskie National Park & 0.130 & 0.130 & 0.130 & 0.130 & 0.072 & 0.072 & 0.071 & 0.075 & 0.069 \\
\hline Polesie National Park & 0.025 & 0.025 & 0.024 & 0.029 & 0.029 & 0.029 & 0.042 & 0.045 & 0.050 \\
\hline Ujście Warty National Park & 0.025 & 0.012 & 0.025 & 0.070 & 0.067 & 0.063 & 0.065 & 0.053 & 0.043 \\
\hline Magura National Park & 0.026 & 0.026 & 0.023 & 0.021 & 0.026 & 0.020 & 0.020 & 0.026 & 0.026 \\
\hline Drawa National Park & 0.021 & 0.019 & 0.042 & 0.022 & 0.017 & 0.016 & 0.019 & 0.014 & 0.011 \\
\hline Biebrza National Park & 0.007 & 0.005 & 0.005 & 0.005 & 0.005 & 0.005 & 0.006 & 0.007 & 0.008 \\
\hline Narew National Park & 0.010 & 0.017 & 0.014 & 0.016 & 0.005 & 0.021 & 0.020 & 0.003 & 0.004 \\
\hline
\end{tabular}


It should be emphasized that the tourist utilization of the parks is strongly determined by their degree of development, which allows for a legal penetration of the area along tourist trails. The analysis of the tourist traffic intensity on the trails reveals that the greatest number of tourists per trail kilometre is observed in Wolin National Park, where there are almost 30 thousand people per trail kilometre each year. There are over 25 thousand on the trails of Pieniny National Park and 15 thousand in Karkonosze National Park. The lowest tourist traffic intensity is reported for Biebrza National Park and Drawa National Park (0.1 thousand each) (Table 4).

Table 4. Number of tourists visiting Polish national parks in 2006-2017 in thousands per trail kilometre.

\begin{tabular}{|c|c|c|c|c|c|c|c|c|c|c|c|c|}
\hline \multirow{2}{*}{ Park Name } & \multicolumn{12}{|c|}{ Tourist Traffic Intensity (in thousands per $1 \mathrm{~km}$ of trail) } \\
\hline & 2006 & 2007 & 2008 & 2009 & 2010 & 2011 & 2012 & 2013 & 2014 & 2015 & 2016 & 2017 \\
\hline Wolin National Park & 31.9 & 31.9 & 29.9 & 29.9 & 29.9 & 29.9 & 29.9 & 29.9 & 29.9 & 29.9 & 29.9 & 29.9 \\
\hline Pieniny National Park & 22.0 & 23.0 & 21.5 & 23.8 & 17.2 & 20.3 & 22.0 & 21.0 & 20.5 & 23.3 & 26.6 & 25.7 \\
\hline Karkonosze National Park & 17.0 & 17.0 & 17.0 & 17.0 & 17.0 & 17.0 & 17.0 & 16.9 & 16.9 & 16.9 & 16.5 & 15.9 \\
\hline Tatra National Park & 9.7 & 8.1 & 7.6 & 8.0 & 7.3 & 8.1 & 10.7 & 10.1 & 11.2 & 12.0 & 13.4 & 13.7 \\
\hline Ojców National Park & 17.4 & 8.6 & 9.8 & 10.1 & 10.1 & 10.1 & 10.7 & 10.7 & 10.7 & 10.7 & 11.4 & 11.5 \\
\hline Roztocze National Park & 1.7 & 1.6 & 2.0 & 1.6 & 3.3 & 3.3 & 4.1 & 4.1 & 4.1 & 4.6 & 6.4 & 6.9 \\
\hline Białowieża National Park & 6.2 & 3.7 & 2.1 & 4.3 & 3.9 & 3.2 & 2.7 & 2.7 & 2.7 & 3.0 & 3.7 & 5.6 \\
\hline Wielkopolski National Park & 5.6 & 5.6 & 5.6 & 5.6 & 5.6 & 5.6 & 5.6 & 5.6 & 5.6 & 5.6 & 5.6 & 5.2 \\
\hline Stołowe Mountains National Park & 1.8 & 2.1 & 2.0 & 3.4 & 1.9 & 1.7 & 3.2 & 3.2 & 3.4 & 4.4 & 2.6 & 4.7 \\
\hline Świętokrzyski National Park & 5.0 & 4.3 & 5.1 & 4.5 & 3.9 & 5.2 & 4.3 & 4.0 & 3.3 & 3.2 & 3.5 & 3.5 \\
\hline Ujście Warty National Park & 1.4 & 1.6 & 1.6 & 1.5 & 0.8 & 1.5 & 4.3 & 4.0 & 3.0 & 3.1 & 2.6 & 2.1 \\
\hline Słowiński National Park & 2.5 & 1.9 & 1.9 & 2.7 & 2.2 & 2.2 & 2.2 & 2.1 & 2.0 & 2.1 & 2.0 & 1.9 \\
\hline Kampinoski National Park & 2.8 & 2.8 & 2.8 & 1.8 & 1.8 & 1.8 & 1.8 & 1.8 & 1.8 & 1.8 & 1.8 & 1.8 \\
\hline Babia Góra National Park & 1.5 & 1.2 & 1.0 & 1.3 & 1.0 & 1.4 & 1.1 & 1.5 & 1.4 & 1.5 & 2.3 & 1.5 \\
\hline Bieszczady National Park & 1.0 & 1.4 & 1.1 & 1.4 & 2.0 & 0.7 & 0.6 & 0.7 & 0.8 & 0.8 & 1.0 & 1.1 \\
\hline Gorce National Park & 0.5 & 0.6 & 0.6 & 0.5 & 0.4 & 0.4 & 0.5 & 0.5 & 0.5 & 0.5 & 0.5 & 0.5 \\
\hline Magura National Park & 0.6 & 0.6 & 0.6 & 0.6 & 0.5 & 0.5 & 0.5 & 0.5 & 0.4 & 0.4 & 0.5 & 0.5 \\
\hline Wigry National Park & 0.5 & 0.5 & 0.5 & 0.5 & 0.4 & 0.4 & 0.4 & 0.4 & 0.4 & 0.4 & 0.5 & 0.5 \\
\hline Polesie National Park & 0.5 & 0.2 & 0.2 & 0.3 & 0.2 & 0.2 & 0.2 & 0.2 & 0.2 & 0.4 & 0.4 & 0.4 \\
\hline Narew National Park & 0.1 & 0.1 & 0.1 & 0.2 & 0.2 & 0.2 & 0.2 & 0.3 & 0.3 & 0.3 & 0.4 & 0.4 \\
\hline Bory Tucholskie National Park & 0.6 & 0.6 & 0.8 & 0.8 & 0.8 & 0.8 & 0.7 & 0.4 & 0.4 & 0.4 & 0.4 & 0.3 \\
\hline Biebrza National Park & 0.1 & 0.1 & 0.1 & 0.1 & 0.1 & 0.1 & 0.1 & 0.1 & 0.1 & 0.1 & 0.1 & 0.1 \\
\hline Drawa National Park & 0.2 & 0.1 & 0.2 & 0.1 & 0.1 & 0.3 & 0.2 & 0.1 & 0.1 & 0.1 & 0.1 & 0.1 \\
\hline
\end{tabular}

Source: own elaboration based on Statistics Poland [108].

\subsection{Primary Research}

The research conducted in national parks indicates that park management is carried out in a conscious and responsible manner, with full respect for sustainable development principles. The directors of all the studied parks issued ordinances specifically regulating the way and scope of making the park available, as well as visitor limits, and seven parks had a conservation plan. In all parks, sightseeing was allowed on marked tourist trails, educational or walking paths, public roads, and other accessible areas. Everywhere, educational activity was carried out and educational pathways were established. In addition, regulations were developed concerning the specific way of making the park available.

\subsubsection{Science and Documentation}

A very important document for the proper operation and management of a park is the conservation plan. In accordance with Article 18 Item 2 of the act on nature conservation [102], a conservation plan for a national park should be created within five years after the park's establishment. Unfortunately, only seven parks have such a plan. Some of them have submitted drafts of the conservation plans to the Minister, while others are in the process of inventorying the natural resources and developing surveys. They are currently working on conservation tasks. In order to limit the negative effects of tourist traffic in national parks, the lists of restrictions to be observed by visitors are indicated. Moreover, park directors issue ordinances through which they shape the individual policy of making 
the national park available. The ordinances determine, among others, the number of people who can stay in a given place at the same time or the amount of admission fees. In all parks, sightseeing was allowed on marked tourist trails, educational or walking paths, public roads, and other accessible areas. In addition, regulations were developed concerning the specific way of making the park available and use of particular places and facilities of the park.

In all parks, a scientific council was established, whose tasks included assessing the state of resources, formations, and components of nature, providing opinions on conservation plan and conservation task projects, assessing the conservation plan implementation, and providing opinions on research and scientific programmes in the field of nature conservation.

\subsubsection{Tourist Issues}

All the investigated parks promote environmentally friendly forms of tourist activity. The sites that may be made available and the maximum number of people who may simultaneously stay at these sites were defined in the conservation plan or, in the case of some parks, until the plan was developed, in the conservation tasks. Making a national park accessible is associated with ensuring safety for nature and visitors; therefore, visitor limits are introduced. The number of people visiting the park is usually estimated by the park employees on the basis of the number of sold tickets, maps, and publications about the park, by direct counting tourists crossing the park entrances, as well as with electronic sensors for monitoring tourist traffic.

In 21 parks, tourist traffic was monitored, the impact of tourism on the park nature condition was analysed and assessed, and, if necessary, measures were taken to minimize the traffic. All parks modernized their tourist infrastructure. However, not all parks introduced visitor limits, and the directors claimed that the traffic should not be restricted but educational activities should be undertaken to raise the culture of sightseeing. Camping was only allowed in 10 parks. In order to protect the most valuable resources from excessive tourist traffic, the trails were led in a way that avoided these places. Entry fees were collected in 16 parks. To reduce the impact of tourism on the environment, channelling and zoning principles were introduced, which mean that tourists can only move along established trails and stay in selected places. The zoning principle denotes the adjustment of tourist traffic intensity to the natural value of the area.

\subsubsection{Educational Issues}

As indicated in Article 8b Item 1 Points 2 and 3 of the act on nature conservation [102], making the park accessible and conducting activities related to nature education are among the tasks of national parks. These should be carried out in accordance with the rules set out in the conservation plan, conservation tasks, and the ordinances of the national park director, and only in a way that will not adversely affect the nature of the park (Article 12 Item 1). National park tasks also involve providing information on and promoting nature conservation, including running a nature museum, information and education centres, and publishing information and promotion materials. All parks implemented ecological education, established educational pathways, and cooperated with local government units. Educational activities were conducted in the form of field lessons, workshops, and lectures. The basic objectives of education were to shape appropriate attitudes to nature in children, youth, and all park visitors, to broaden the knowledge related to nature conservation, and to familiarize people with the principles of park accessibility.

\subsubsection{Environmental Threats}

The research carried out and the provisions included in the conservation tasks established by the Minister of Environment indicate that certain aspects of tourism in the parks have been identified as factors threatening or potentially threatening the parks' nature. However, in general, tourism itself is not a threat if it is well managed and when counter-measures are taken. The parks analyse the environmental impact of tourism in various ways. They implement projects, perform research, monitor 
changes in the natural environment. Students and academics often conduct research as part of their master theses and scientific articles. On the basis of the analyses of threats related to the anthropogenic impact on the environment, water erosion, as well as the distribution and intensity of tourist traffic, the limits of people who can stay in a given place at a given time are defined. The conducted analyses of the impact of tourist traffic on the parks' nature often result in excluding routes from tourist traffic because of trampling plants by tourists.

Among the various types of research on the flora and fauna of the parks, the most common are the following:

- Soil condition monitoring;

- Monitoring the condition, quantity, and quality of surface water and groundwater;

- Meteorological monitoring;

- Monitoring at selected water stations;

- Monitoring of selected species or groups of plants and animals.

The analysis of the obtained results reveals the highest conformity in all investigated national parks in the following areas: creating regulations on making the park accessible, the presence of the park scientific council, undertaking promotion activities in the field of friendly forms of tourist activity, the modernization of the existing tourist infrastructure, ecological education, introducing educational pathways, cooperation with local government units, monitoring the impact of tourism on the environment, and assessing the impact of tourism on the environment.

All these issues have been identified as crucial in the implementation of strategic objectives for the conservation and development of parks $(\mathrm{AI}=1.0)$ (Table 5).

The lowest AI was obtained in the field of natural environment conservation plan development $(\mathrm{AI}=0.30)$ and tourism as a potential threat to parks' nature $(\mathrm{AI}=0.39)$. The designation of camping areas was also rarely considered $(\mathrm{AI}=0.43)$.

The division of the investigated parks into those that were UNESCO biosphere reserves and those that were not classified in this category allowed us to state that UNESCO biosphere reserves more often charged entrance fees $(\Delta \mathrm{AI}=0.32)$, more often developed natural environment conservation plans $(\triangle \mathrm{AI}=0.23)$, and more often considered tourism as an existing or potential threat for park nature $(\triangle \mathrm{AI}=0.27)$. Managers of UNESCO biosphere reserves less frequently introduced tourist traffic limits $(\triangle \mathrm{AI}=-0.13)$ and less frequently designated camping areas $(\Delta \mathrm{AI}=-0.17)$.

The differences observed in terms of the division of the investigated parks into coast, lake district, lowland, upland, and mountain ones revealed that nature conservation plans were more often developed in mountain parks $(\mathrm{AI}=0.50)$. Similarly, revenues from admission fees were most often reported in mountain parks $(\mathrm{AI}=0.88)$, and least frequently in coast parks $(\mathrm{AI}=0.50)$. Camping areas were more often introduced in lake district parks $(\mathrm{AI}=0.80)$, less frequently in mountain $(\mathrm{AI}=0.38)$ and lowland parks $(\mathrm{AI}=0.40)$. These restrictions were not applied in coast parks $(\mathrm{AI}=0.00)$. Tourist traffic limits were more often noted in lake district $(\mathrm{AI}=0.80)$ and upland parks $(\mathrm{AI}=0.67)$ than in mountain parks $(\mathrm{AI}=0.38)$. No tourist traffic limits were reported in coast parks $(\mathrm{AI}=0.0)$. 
Table 5. Acceptance index: research results.

\begin{tabular}{|c|c|c|c|c|c|c|c|c|}
\hline \multirow[t]{2}{*}{ Acceptance Index } & \multirow[t]{2}{*}{$\stackrel{\frac{\pi}{0}}{\circ}$} & \multicolumn{2}{|c|}{$\begin{array}{l}\text { UNESCO } \\
\text { Biosphere } \\
\text { Reserve }\end{array}$} & \multicolumn{5}{|c|}{ Park Type } \\
\hline & & Yes & No & $\begin{array}{l}\overrightarrow{0} \\
\text { ठ̊ }\end{array}$ & 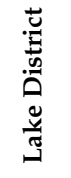 & 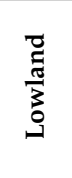 & 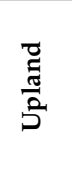 & 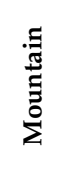 \\
\hline 1. Natural environment conservation plan & 0.30 & 0.44 & 0.21 & 0.00 & 0.20 & 0.20 & 0.33 & 0.50 \\
\hline 2. Regulations on making the park accessible & 1.00 & 1.00 & 1.00 & 1.00 & 1.00 & 1.00 & 1.00 & 1.00 \\
\hline 3. Scientific council & 1.00 & 1.00 & 1.00 & 1.00 & 1.00 & 1.00 & 1.00 & 1.00 \\
\hline 4. Promoting friendly forms of tourist activity & 1.00 & 1.00 & 1.00 & 1.00 & 1.00 & 1.00 & 1.00 & 1.00 \\
\hline 5. Tourist traffic limits & 0.52 & 0.44 & 0.57 & 0.00 & 0.80 & 0.60 & 0.67 & 0.38 \\
\hline $\begin{array}{l}\text { 6. Restrictions on tourism development in areas } \\
\text { under impact }\end{array}$ & 0.65 & 0.67 & 0.64 & 0.50 & 0.60 & 0.80 & 0.67 & 0.63 \\
\hline 7. Designated camping areas & 0.43 & 0.33 & 0.50 & 0.00 & 0.80 & 0.40 & 0.33 & 0.38 \\
\hline 8. Tourist traffic monitoring & 0.91 & 0.89 & 0.93 & 1.00 & 1.00 & 0.80 & 0.67 & 1.00 \\
\hline $\begin{array}{l}\text { 9. Modernization of the existing tourist } \\
\text { infrastructure }\end{array}$ & 1.00 & 1.00 & 1.00 & 1.00 & 1.00 & 1.00 & 1.00 & 1.00 \\
\hline 10. Revenues from admission fees & 0.70 & 0.89 & 0.57 & 0.50 & 0.60 & 0.60 & 0.67 & 0.88 \\
\hline 11. Ecological education & 1.00 & 1.00 & 1.00 & 1.00 & 1.00 & 1.00 & 1.00 & 1.00 \\
\hline 12. Educational pathways & 1.00 & 1.00 & 1.00 & 1.00 & 1.00 & 1.00 & 1.00 & 1.00 \\
\hline 13. Cooperation with local government units & 1.00 & 1.00 & 1.00 & 1.00 & 1.00 & 1.00 & 1.00 & 1.00 \\
\hline 14. Tourism as an existing or potential threat & 0.39 & 0.56 & 0.29 & 0.00 & 0.40 & 0.00 & 0.67 & 0.63 \\
\hline 15. Indicators for sustainable tourism planning & 0.65 & 0.67 & 0.64 & 0.50 & 0.80 & 0.80 & 0.33 & 0.63 \\
\hline $\begin{array}{l}\text { 16. Monitoring the impact of tourism on the } \\
\text { environment }\end{array}$ & 1.00 & 1.00 & 1.00 & 1.00 & 1.00 & 1.00 & 1.00 & 1.00 \\
\hline $\begin{array}{l}\text { 17. Assessing the impact of tourism on the } \\
\text { environment }\end{array}$ & 1.00 & 1.00 & 1.00 & 1.00 & 1.00 & 1.00 & 1.00 & 1.00 \\
\hline
\end{tabular}

Source: own elaboration.

\section{Model of Environmental Management System}

The study results allow us to create a model system of managing the natural environment in the park. It includes diagnosis, planning, responsibility allocation, documentation, monitoring, and measurement. Such management addresses environmental concerns. The system is a set of tools that allow us to apply environmental policy, which leads to minimizing the harmful impact on the environment in a way that is beneficial to both tourists and the environment (Figure 3). 


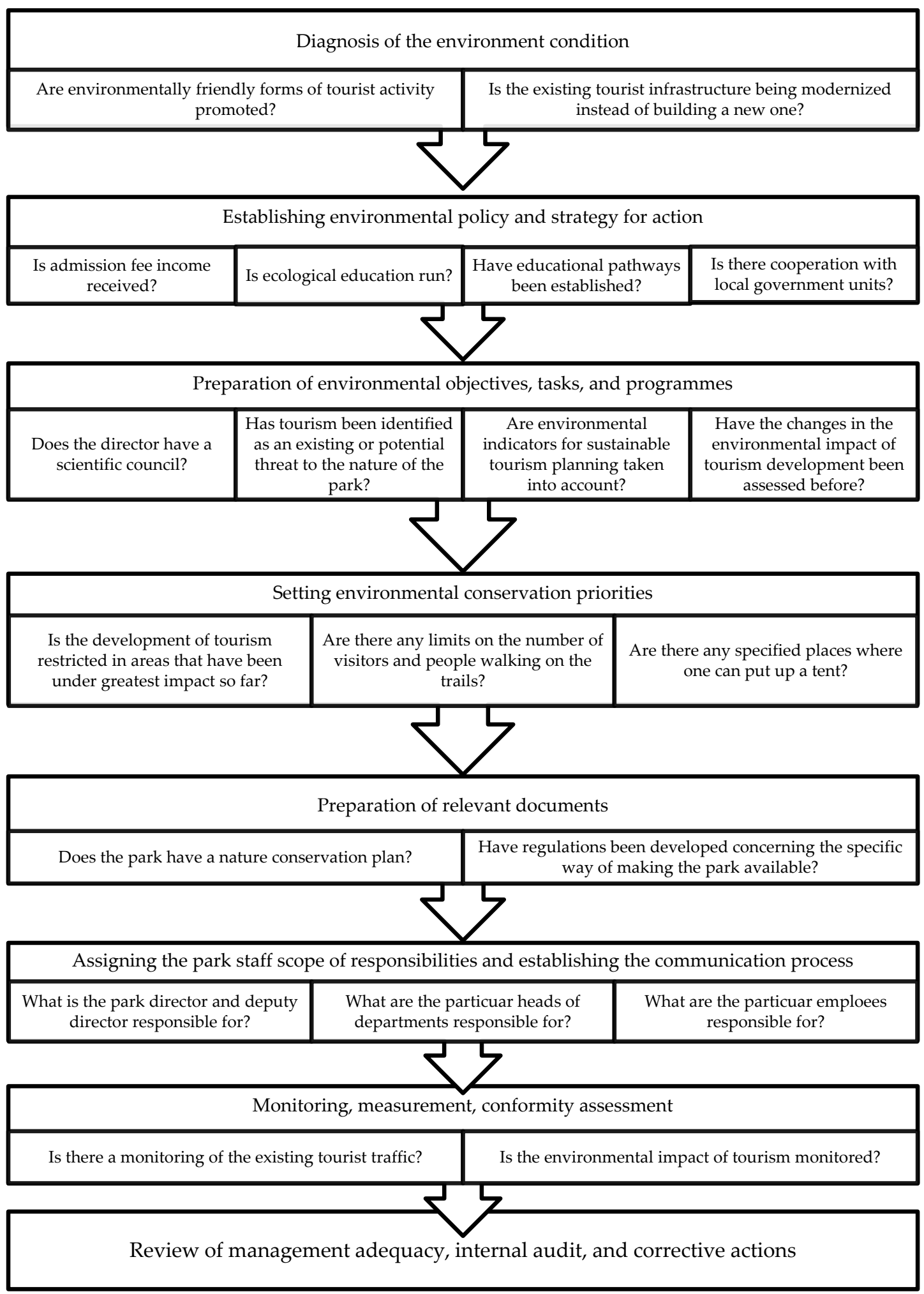

Figure 3. Model system of managing the natural environment in a national park; (source: own elaboration).

The model proposed by the authors consists of seven main parts:

1. The diagnosis of the environment condition. The most important issue is to diagnose the condition of the environment, i.e., to determine the environmental impact of any element that may threaten it. It is necessary to identify the environmental problems. This should be performed by means 
of appropriate tools, such as questionnaire surveys, in-depth interviews, direct inspections and measurements, and random checks.

2. Establishing environmental policy and a strategy for action. The next step is to establish an appropriate policy, i.e., all intentions and ways of operating with regard to environmental activities. Environmental policy provides a framework for action and setting environmental objectives and tasks.

3. The preparation of environmental objectives, tasks, and programmes. The environmental objective should be measurable and consistent with the environmental policy. In turn, environmental tasks are detailed requirements for activity effects, resulting from the environmental objectives. Environmental objectives may, for example, include commitments to minimize all significant negative environmental impacts or to promote environmental awareness among young people and the local community.

4. Setting environmental conservation priorities. These are actions aimed at identifying priorities for action and quickly minimizing negative environmental impacts. They consist of managing key processes in the park related to important environmental aspects.

5. The preparation of relevant documents. The documentation should include environmental policy, objectives and tasks, the responsibilities and duties of employees, information on environmental aspects, records of monitoring the effects of environmental conservation activities, and the organization of training courses.

6. Assigning the park staff scope of responsibilities and establishing the communication process. This denotes indicating the park employees' tasks for which they will be responsible. The responsibilities may include, among others, the implementation, maintenance, and improvement of environmental conservation measures, coordination of teamwork, supervision of the identification and assessment of environmental aspects, ensuring monitoring, ensuring compliance with legal requirements, ensuring continuous improvement.

7. Monitoring, measurement, and conformity assessment. Inconsistencies may relate to the failure to meet the legal provisions on environmental conservation, deviations from environmental policy, and related environmental objectives and tasks, failure to meet the adopted criteria for particular activities and processes as revealed in the course of monitoring.

\section{Discussion on the New Paradigm of National Park Management}

National parks are characterized by high natural values, which make them attractive areas of tourist use. Therefore, the question is whether sustainable natural environment management can be carried out in national parks. Examples should be sought in similar environmentally valuable areas not only in Europe, but also in the world. Out of the 220 national parks in Europe, almost half are mountain parks; they are most numerous in the Scandinavian Mountains and the Carpathians. The tourist traffic in European mountain national parks is highly diversified; in Scandinavian parks, it is small, in contrast to Alpine parks where, owing to good transport accessibility and tourist infrastructure, visitors are numerous. The results obtained by the authors are in line with many foreign studies related to similar issues, although in other areas. The impact of human activity on our natural environment is remarkable. The environmental threats analysed by the authors are monitored in many countries. These problems were specifically referred to by Chemini and Rizzoli [24]. They conducted their research in the Alps; they pointed out that a large part of these mountains biodiversity was linked to the interaction between the natural environment and traditional human activity. Today, land-use transformations and other environmental and socio-economic processes, such as urbanization, tourism, or pollution, are significant forces for environmental change. The researchers indicated that mowing and the grazing of livestock were major factors inhibiting tree succession in many regions of the Alps. In turn, abandoning mountain fields and meadows causes the expansion of shrubs and forests and reduces the number of grass species. The environmental threats also result from the urbanization of the areas around the parks. Elmi and Perlik [65] performed research in the Alps too. They decided to investigate 
the reappearance of residents in the mountainous parts of the Alps. They asked whether this influx was more than just a selective development of urban areas, and whether this could also be confirmed for peripheral areas. They also sought answers to the question about the driving forces behind this migration. The explanations are complex, as they need the consideration of the relationships between the permanent population and second home owners. On the basis of empirical data collected at the municipality level in five different provinces in the eastern Alps, the mentioned authors implied that the consistent settlement of new residents was only selective. This trend is focused on areas that can count on good transport accessibility, located mainly in urban and suburban municipalities. Similarly, Barker [47] raised the important issue of mass tourism expansion in various mountain regions of the world. He pointed at ski resorts and the emerging conflicts between environmental conservation and the desire to expand the resorts. In the USA, the effects were stronger than in Europe, where successful investments in tourism do not currently burden the landscape so much. The author investigated mass tourism, and the findings indicate solutions valuable for other mountain regions.

The presented paper is focused on tourism issues. The respondents indicated benefits and threats for the park resulting from tourism. They also highlighted investments in infrastructure and security. The advantages of natural resources for tourism were also studied by Gios et al. [111]. They specified that, in several Alpine regions, the transition to a tourism economy was due to major capital investment. However, the management of an environmentally valuable area does not allow for a high level of investment in hotels or guesthouses that would guarantee income from the use of natural resources; the only possible tourism is one compatible with maintaining high-quality natural environments. Unfortunately, this type of tourism has few benefits for local communities. In fact, tourists only degrade the land and infrastructure on which tourism itself is based. Car traffic damages unpaved roads, mountain bikes destroy paths and meadows, and infrastructure maintenance becomes a burden on the local community. Therefore, researchers are asking how to manage such an area, indicating that it is not an easy duty. However, an opportunity should be seen in the development of projects based on European Union programmes. A solution can also be to impose admission fees for visitors. At present, this seems impractical, even if it could be implemented in the future. In addition to the technical difficulties involved in collecting entrance fees, the sensitivity of tourists does not yet seem mature enough to accept payment. Another solution could be to create a network of lightweight infrastructure that would enable rational use of natural resources and attract tourists, and thus create jobs in the vicinity. Moreover, Gios et al. [111] pointed at interesting solutions for sustainable tourism that are possible to apply in Polish national parks. They also confirmed that a high level of investment in hotels or guesthouses, similar to in Poland, was not possible in such valuable natural areas. A similar subject was raised in relation to the German Alps by Paunović and Jovanović [62]. Their research focused on threats to sustainable development, tourism, as well as cross-border cooperation and stakeholder involvement. The findings imply that only a comprehensive approach to disseminating knowledge about sustainable development can be the basis for mountain tourism development. The implementation should focus on specific sustainable tourism flagship products. Cross-border cooperation and stakeholder involvement turned out to be crucial.

An important issue is the management process in the development of a tourist centre. The authors of the present study devoted a lot of attention to this matter. A similar subject was referred to by Bonzanigo et al. [112]. Their article presents the development and application of a management process for the local development of an Alpine tourist resort. The researchers pointed out that an efficient combination of modelling, decision making, and participatory processes could significantly improve decisions regarding sustainable development. They showed that such a combination of methods and tools allowed to manage the involvement of local actors and stimulate local debates on adaptation to climate changes and possible consequences for winter tourism. They also recommended encouraging creativity and mitigating potential conflicts. This contributed to the development of alternative sustainable tourism planning strategies. Moreover, various management methods are indicated that can be used in Polish national parks. 
The aim of the article was to create a universal model of national park management, to develop a sustainable way of reconciling the increasing tourist traffic and nature conservation. A similar challenge was taken up by Coban and Yildiz [113]. The proposed model aims to make Cappadocia tourism more sustainable and competitive. The researchers implied that destination management organizations increased cooperation and coordination among stakeholders and contributed to the destination competitiveness. The authors interviewed stakeholders to identify problems in Cappadocia tourism and to suggest solutions. The main challenges were related to infrastructure, accessibility, human resources, sustainable development, and the environment. A well-prepared management system can help the region become more competitive, at the same time minimizing current problems. Cooperation and coordination were identified as key functions owing to the presence of several tourism management institutions in Cappadocia. The research provides a powerful input in the debate on a model approach to sustainable and competitive tourism. Directors of Polish national parks can take advantage of the recommendations presented in the study.

\section{Conclusions and Recommendations}

Managing the use, conservation, and formation of the natural environment is a very complex process. The principal objective is to ensure conservation and gain certainty that resources will remain available for future generations, as well as to improve the adverse effects of human activity and the overall state of the natural environment.

The purpose of the paper was to attempt to present a model of natural environment management in national parks in Poland in the context of increased tourist traffic. The assumed goal was achieved owing to in-depth interviews with the management staff of the parks. Their indications allowed us to create a comprehensive system of both nature conservation and making nature available to tourists.

Three issues are particularly important from the point of view of a national park activity. The first one is the competence of the management bodies, as they have the best knowledge of the problems occurring in the park and should be able to directly influence them. The second issue is the legal obligation of parks to provide environmental education, so important in the modern world. The third issue is a good environmental management system, essential for sustainable management. The obtained results can be grouped into the following three categories:

1. Administrative and management bodies In order for the activities to have an impact on the park area, a carefully developed conservation plan should be developed. The research indicates that only seven parks actually had such a plan; some have submitted draft conservation plans to the Minister, while others were in the process of inventorying the natural resources and developing surveys. Its correctness requires research monitoring the state of the environment, the size and trends of the tourist traffic, and tourists' impact on the environment. An important condition for a more effective tourism management in parks is to increase the competences of the administering bodies and the knowledge regarding individual responsibilities. Boards should be able to analyse, evaluate, and modify not only conservation plans, but also spatial development plans, municipality development strategies, and projects for investments planned within the parks. The sustainable development of tourism in parks is not possible without the involvement of local communities and their taking real advantages of tourism. From this point of view, the most favourable is the development of agritourism, which provides employment for the residents; therefore, cooperation with local governments plays a significant role.

2. Education The research reveals that all parks implemented ecological education, established educational pathways, and cooperated with local government units. These actions, however, are insufficient. More attention should be paid to education and the promotion of ecological behaviour among tourists and local communities. This is due to the diversified level of their culture and identification with the park area, which depends on the history of development and traditions of these communities. A widespread lack of awareness of the negative impact of human activity on the environment usually leads to the degradation of natural and landscape 
values, which determine the attractiveness of the area. Economic instruments have the greatest contribution to the effective management of environmental resources, as they can influence or force reasonable actions for the natural environment.

3. Management system The research results obtained in Polish national parks indicate that their management is carried out in a non-accidental and reliable manner in relation to sustainable development principles. It was revealed that certain aspects of tourism in the parks were considered to be factors threatening or potentially threatening the nature of the park. However, in general, tourism itself is not a threat if it is well managed and if preventive measures are taken. The directors of the investigated parks try to include selected elements of the proposed model in the management process. However, only their comprehensive application can bring success. The proposed model of the system of natural environment management in a park may be implemented as a good practice in other state parks around the world. The modern management of the natural environment in such valuable areas as national parks can reconcile two very difficult issues, namely nature conservation and its simultaneous availability to tourists. In a national park, natural resources, i.e., ecosystems and their appropriate conservation, are always in the front line; however, wisely conducted tourism does not have to produce negative effects. In the future, the proposed concept of the park management system may also find wide application in other institutions and companies that prioritize environmental conservation.

The model proposed by the authors has been verified in state-run national parks and is addressed to them. Unfortunately, in private national parks, the model would have to be modified and adjusted to the needs of the park owner. Among the first owners of private national parks are Douglas Tompkins, Ted Turner, and Roxanne Quimby. Creating their policy of managing national parks, they have become leaders in the struggle to save the Earth for future generations.

Author Contributions: P.O. prepared the following elements of the article: the methodology, conclusions; S.P. prepared the following elements of the article: the methodology, conduct of research, developed the final contents of the article and proofread and revised it. J.M.-P. prepared the following elements of the article: the methodology, introduction, review of the literature. A.R.S. prepared the following elements of the article: the methodology, introduction and conclusions, conduct of research, calculations. S.J.- -review and editing, data correction. All authors have read and agreed to the published version of the manuscript.

Funding: This research received funding by the National Science Center in Poland. The funders had no role in the design of the study; in the collection, analyses, or interpretation of data; in the writing of the manuscript, or in the decision to publish the results.

Acknowledgments: This paper was published as part of the research project 'A business model for health resort enterprises' No. 2017/25/B/HS4/00301, supervised and financed by the National Science Center in Poland and as part of statutory research No. BK-235/ROZ-1/2020 (13/010/BK_20/0042) at the Silesian University of Technology, Faculty of Organization and Management.

Conflicts of Interest: The authors declare no conflict of interest.

\section{References}

1. Burchard-Dziubińska, M.; Rzeńca, A.; Drzazga, D. Zrównoważony Rozwój: Naturalny Wybór; Wydawnictwo Uniwersytetu Łódzkiego: Lodz, Poland, 2014.

2. Michalski, E. Zarzadzanie Przedsiębiorstwem: Podręcznik Akademicki; Wydawnictwo Naukowe PWN: Warsaw, Poland, 2013.

3. Wei, Y.; He, S.; Li, G.; Chen, X.; Shi, L.; Lei, G.; Su, Y. Identifying nature-community nexuses for sustainably managing social and ecological systems: A case study of the Qianjiangyuan National Park pilot area. Sustainability 2019, 11, 6182. [CrossRef]

4. Luque-Martínez, T.; Faraoni, N.; Doña-Toledo, L. Auditing the marketing and social media communication of natural protected areas. How marketing can contribute to the sustainability of tourism. Sustainability 2019, 11, 4014. [CrossRef]

5. Deng, J.; Li, J. Segmentation of nature-based tourists in a rural area (2008-2009): A single-item approach. Sustainability 2019, 11, 2052. [CrossRef] 
6. Myga-Piatek, U.; Jankowski, G. Wpływ turystyki na środowisko przyrodnicze i krajobraz kulturowy-Analiza wybranych przykładów obszarów górskich. Probl. Ekol. Krajobr. 2009, 25, 27-38.

7. Krupa, J. Działania proekologiczne w turystyce szansą na jej zrównoważony rozwój. Zesz. Nauk. Tur. Rekr. 2014, 1, 5-23.

8. Mizgajski, A. Zarzadzanie środowiskiem i jego pozycja w badaniach geograficznych. Przegl. Geogr. 2008, 80, 23-37.

9. Ackerman, E. Where is a research frontier? Ann. Assoc. Am. Geogr. 1963, 53, 429-440. [CrossRef]

10. Hagerstrand, T. Geografia i badania zależności pomiędzy naturą a społeczeństwem. Przegl. Zagr. Lit. Geogr. 1979, 4, 35-46.

11. Bartkowski, T. Zastosowania Geografii Fizycznej; PWN: Warsaw, Poland, 1986.

12. Barbag, J. Przedmiot i zadania geografii regionalnej. Przegl. Geogr. 1959, 31, 495-515.

13. Zube, E.H. Local and extra-local perceptions of national parks and protected areas. Landsc. Urban Plan. 1986, 13, 11-17. [CrossRef]

14. Zube, E.H.; Busch, M.L. Park—People relationship: An international review. Landsc. Urban Plan. 1990, 19, 117-131. [CrossRef]

15. West, P.C.; Brechin, S.R. (Eds.) Resident Peoples and National Parks: Social Dilemmas and Strategies in International Conservation; University of Arizona Press: Tucson, AZ, USA, 1991.

16. Beltran, J. (Ed.) Indigenous and Traditional Peoples and Protected Areas: Principles, Guidelines and Case Studies; Best Practice Protected Areas Guildelines Series, No 4; WWF/IUCN: Gland, Switzerland, 2000.

17. Macgill, S.M. Environmental questions and human geography. Int. Soc. Sci. J. 1986, 38, 357-375.

18. Kantowicz, E.; Skotnicki, M. Główne problemy i tendencje w geografii regionalnej. In Podstawowe Problemy Metodologiczne Polskiej Geografii; Chojnicki, Z., Ed.; Wydawnictwo Naukowe UAM: Poznan, Poland, 1991; pp. 229-243.

19. Dumanowski, B. Geografia regionalna jako dyscyplina badawcza. Przegl. Geogr. 1981, 53, 87-94.

20. Kostrzewski, A. (Ed.) Geografia Regionalna Jako Przedmiot Badań i Nauczania; Bogucki Wydawnictwo Naukowe: Poznan, Poland, 2006.

21. Gocłowski, A.; Kałuski, S.; Kantowicz, E.; Walewski, A. Geografia regionalna. In Historia Geografii Polskiej; Jackowski, A., Liszewski, S., Richling, A., Eds.; Wydawnictwo Naukowe PWN: Warsaw, Poland, 2008; pp. 248-260.

22. Fraser, I.; Chisholm, T. Conservation or cultural heritage? Cattle grazing in the Victoria Alpine National Park. Ecol. Econ. 2000, 33, 63-75. [CrossRef]

23. West, P.; Igoe, J.; Brockington, D. Parks and peoples: The social impact of protected areas. Ann. Rev. Anthropol. 2006, 35, 251-277. [CrossRef]

24. Chemini, C.; Rizzoli, A. Land use change and biodiversity conservation in the Alps. J. Mt. Ecol. 2003, 7, 1-7.

25. Domański, R. Metody badania zbieżności układów przestrzennych. Przegl. Geogr. 1969, 41, 79-92.

26. Walewski, A. Badanie relacji między zmiennymi o wartościach grupowanych. Propozycja metodyczna. Pr. Stud. Geogr. 1997, 19, 49-54.

27. Walewski, A. Metody badania relacji przyroda-człowiek. Pr. Stud. Geogr. 2004, 34, 75-85.

28. Walewski, A.; Kantowicz, E. The relations between man and the natural environment as the methodological basis for delimitation of regions. Misc. Geogr. 2010, 14, 295-301. [CrossRef]

29. Domański, R. Konstruowanie teorii w geografii ekonomicznej. Przegl. Geogr. 1967, 1, 85-102.

30. Domański, R. Systemy Ekologiczno-Ekonomiczne. Modelowanie Wspótzależności i Rozwoju; PAN: Warsaw, Poland, 1992.

31. Kistowski, M. Regionalny Model Zrównoważonego Rozwoju i Ochrony Środowiska Polski a Strategie Rozwoju Województw; Bogucki Wydawnictwo Naukowe: Gdansk/Poznan, Poland, 2003. 
32. Kistowski, M. Próba typologii sytuacji konfliktowych w relacjach „zagospodarowanie przestrzenne-środowisko przyrodnicze" na obszarze parków krajobrazowych nad Zatoką Gdańska. In Między Ochrona Przyrody a Gospodarka_Bliżej Ochrony. Konflikty Człowiek-Przyroda W Obszarach Prawnie Chronionych w Polsce; Hibszer, A., Partyka, J., Eds.; PTG Oddział Katowicki: Sosnowiec, Poland, 2005; pp. 18-31.

33. Butler, R.W. Sustainable tourism: A state-of-the-art review. Tour. Geogr. 1999, 1, 7-25. [CrossRef]

34. Pearce, D.G. Westland National Park: Economic Impact Study; University of Canterbury: Christchurch, New Zealand, 1982.

35. Kerr, G.N.; Sharp, B.H.; Gough, J.D. Economic Benefits of Mt. Cook National Park; University of Canterbury and Lincoln College: Christchurch, New Zealand, 1986.

36. Abel, N.; Blaikie, P. Elephants, people, parks and development: The case of the Luangwa Valley, Zambia. Environ. Manag. 1986, 10, 735-754. [CrossRef]

37. Clough, P.W.J.; Meister, A.D. Benefit Assessment of Recreation Land: The Whakapapa Area, Tongariro National Park; Massey University: Palmerston North, New Zealand, 1989.

38. Trakolis, D. Local people's perceptions of planning and management issues in Prespes Lakes National Park, Greece. J. Environ. Manag. 2001, 61, 227-241. [CrossRef] [PubMed]

39. Ferraro, P.J. The local costs of establishing protected areas in low-income nations: Ranomafana National Park, Madagascar. Ecol. Econ. 2002, 43, 261-275. [CrossRef]

40. Cihar, M.; Stankova, J. Attitudes of stakeholders towards the Podyji/Thaya River Basin National Park in the Czech Republic. J. Environ. Manag. 2006, 81, 273-285. [CrossRef] [PubMed]

41. Jarvis, T.D. The Responsibility of National Parks in Rural Development. In National Parks and Rural Development; Machlis, G., Field, D., Eds.; Island Press: Washington, DC, USA, 2000; pp. 219-229.

42. Kideghesho, J.R.; Roskaft, E.; Kaltenborn, B.P. Factors influencing conservation attitudes of local people in western Serengeti, Tanzania. Biodivers. Conserv. 2007, 16, 2213-2230. [CrossRef]

43. Fortin, M.-J.; Gagnon, C. An assessment of social impacts of national parks on communities in Quebec, Canada. Environ. Conserv. 1999, 26, 200-211. [CrossRef]

44. Burger, T. Konflikt i współdziałanie. Świadomość ekologiczna i postawy społeczeństwa. In Świadomość Ekologiczna i Społeczne Ruchy "Zielonych” w Polsce; Mirowski, W., Ed.; IFiS PAN: Warsaw, Poland, 1999; pp. 35-55.

45. Królikowska, K. Między ochroną przyrody a rozwojem na obszarach górskich—konflikty i rozwiązania. Czas. Geogr. 2002, 73, 187-214.

46. Hibszer, A. Parki Narodowe w Świadomości i Działaniach Społeczności Lokalnych; Uniwersytet Ślaski: Katowice, Poland, 2013.

47. Barker, M.L. Traditional landscape and mass tourism in the Alps. Geogr. Rev. 1982, 72, 395-415. [CrossRef]

48. Bauer, H. Local perception of Waza National Park, northern Cameron. Environ. Conserv. 2003, 30, $175-181$. [CrossRef]

49. Bojórquez-Tapia, L.A.; de la Cueva, H.; Diaz, S.; Melgarejo, D.; Alcantar, G.; Solares, M.J.; Grobet, G.; Cruz-Bello, G. Environmental conflicts and nature reserves: Redesigning Sierra San Pedro Martir National Park, Mexico. Biol. Conserv. 2004, 117, 111-126. [CrossRef]

50. Colchester, M. Conservation policy and indigenous people. Environ. Sci. Policy 2004, 7, 145-153. [CrossRef]

51. Stern, M. The power of trust: Toward a theory of local opposition to neighboring protected areas. Soc. Nat. Resour. 2008, 21, 859-875. [CrossRef]

52. Heinen, J.T. Park-people relations in Kosi Tappu Wildlife Reserve, Nepal: A socio-economic analysis. Environ. Conserv. 1993, 20, 25-34. [CrossRef]

53. Lewis, C. Managing Conflicts in Protected Areas; IUCN: Gland, Switzerland, 1996.

54. Odrowąż-Pieniążek, I.; Woźniak, J. Negocjacje jako strategia rozwiązywania konfliktów w sporach pomiędzy parkami narodowymi a samorządami. Człow. Środ. 1997, 21, 87-95.

55. Nepal, S.K. Linking parks and people: Nepal's experience in resolving conflicts in parks and protected areas. Int. J. Sust. Dev. World 2002, 9, 75-90. [CrossRef]

56. Hunter, C.; Green, H. Tourism and the Environment: A Sustainable Relationship? Routledge: London, UK, 1995.

57. Hunter, C. Sustainable tourism as an adaptive paradigm. Ann. Tour. Res. 1997, 24, 850-867. [CrossRef]

58. Draper, D. Toward sustainable mountain communities: Balancing tourism development and environmental protection in Banff and Banff National Park, Canada. Ambio 2000, 29, 408-415. [CrossRef] 
59. Sharpley, R. Tourism and sustainable development: Exploring the theoretical divide. J. Sustain. Tour. 2000, 8, 1-19. [CrossRef]

60. Saarinen, J. Traditions of sustainability in tourism studies. Ann. Tour. Res. 2006, 33, 1121-1140. [CrossRef]

61. Hunter, C. Sustainable tourism and the touristic ecological footprint. Environ. Dev. Sustain. 2002, 4, 7-20. [CrossRef]

62. Paunović, I.; Jovanović, V. Implementation of sustainable tourism in the German Alps: A case study. Sustainability 2017, 9, 226. [CrossRef]

63. Mortensen, T.L.; Leistritz, F.L.; Leitch, J.A.; Coon, R.C.; Ekstrom, B.L. Socioeconomic impact of the conservation reserve program in North Dakota. Soc. Nat. Resour. 1990, 3, 53-61. [CrossRef]

64. Mika, M. Założenia i Determinanty Podtrzymywalności Lokalnego Rozwoju Turystyki; Instytut Geografii i Gospodarki Przestrzennej Uniwersytetu Jagiellońskiego: Krakow, Poland, 2014.

65. Elmi, M.; Perlik, M. From tourism to multilocal residence? Unequal transformation processes in the Dolomites area. J. Alp. Res. 2014, 102. [CrossRef]

66. Pawlaczyk, P. Modele oddziaływań człowiek-przyroda jako podstawa określenia pojemności turystycznej parku narodowego. In Użytkowanie Turystyczne Parków Narodowych. Ruch Turystyczny—Zagospodarowanie-Konflikty—Zagrożenia; Partyka, J., Ed.; Instytut Ochrony Przyrody PAN, Ojcowski Park Narodowy: Ojcow, Poland, 2002; pp. 23-36.

67. Wnuk, Z.; Ziaja, M. (Eds.) Turystyka w Obszarach Natura 2000; Uniwersytet Rzeszowski: Rzeszow, Poland, 2007.

68. Liszewski, S. Przestrzeń turystyczna parków narodowych w Polsce. In Gospodarka i Przestrzeń; Domański, B., Kurek, W., Eds.; Instytut Geografii i Gospodarki Przestrzennej UJ: Krakow, Poland, 2009; pp. 187-201.

69. Zajadacz, A. Koncepcja rozwoju rozwoju turystyki. In Uwarunkowania i Plany Rozwoju Turystyki. Walory $i$ Atrakcje Turystyczne. Potencjał Turystyczny. Plany Rozwoju Turystyki; Seria Turystyka i Rekreacja—Studia i Prace; Naukowe UAM, Ed.; Adam Mickiewicz University: Poznań, Poland, 2009; Volume 3, pp. 93-130.

70. Butler, R.W. The concept of a tourist area cycle of evolution: Implications for management of resources. Can. Geogr. 1980, 24, 5-12. [CrossRef]

71. Brechin, S.R.; West, P.C.; Harmon, D.; Kutay, K. Resident Peoples and Protected Areas: A Framework for Inquiry. In Resident Peoples and National Parks: Social Dilemmas and Strategies in International Conservation; West, P.C., Brechin, S.R., Eds.; University of Arizona Press: Tucson, AZ, USA, 1991; pp. 5-30.

72. Eagles, P.; McCool, S.F. Tourism in National Parks and Protected Areas: Planning and Management; CABI: New York, NY, USA, 2002.

73. Pytel, S. Atrakcyjność turystyczna miejsc migracji seniorów z województwa śląskiego. Ekon. Probl. Tur. 2014, 1,327-340.

74. Markiewicz-Patkowska, J.; Pytel, S.; Widawski, K.; Oleśniewicz, P. Turystyka senioralna w kontekście sytuacji materialnej polskich emerytów. Ekon. Probl. Tur. 2018, 2, 99-106.

75. Pytel, S.; Rahmonov, O. Migration processes and the underlying reasons: A study on pensioner migrants in Poland. Popul. Space Place 2019, 25, e2197. [CrossRef]

76. Stoll-Kleemann, S. Reconciling opposition to protected areas management in Europe: The German experience. Environ. Sci. Policy Sust. Dev. 2001, 43, 32-44. [CrossRef]

77. Kaltenborn, B.P.; Nyahongo, J.W.; Kidegesho, J.R.; Haaland, H. Serengeti National Park and its neighbours-Do they interact? J. Nat. Conserv. 2008, 16, 96-108. [CrossRef]

78. Von Ruschkowski, E. Causes and Potential Solutions for Conflicts Between Protected Area Management and Local People in Germany. In Rethinking Protected Areas in a Changing World: Proceedings of the 2009 George Wright Society Biennial Conference on Parks, Protected Areas, and Cultural Sites in Portland, Oregon; Weber, S., Ed.; George Wright Society: Hancock, MI, USA, 2010; pp. 200-244.

79. Raval, S.R. Wheel of life: Perceptions and concerns of the resident peoples for Gir National Park in India. Soc. Nat. Resour. 1994, 7, 305-320. [CrossRef]

80. Fiallo, E.A.; Jacobson, S.K. Local communities and protected areas: Attitudes of rural residents towards conservation and Machalilla National Park, Ecuador. Environ. Conserv. 1995, 22, 241-249. [CrossRef]

81. Brandon, L.; Redford, K.H.; Sanderson, S.E. (Eds.) Parks in Peril: People, Politics and Protected Areas; Island Press: Washington, DC, USA, 1998.

82. Allendorf, T.D. A framework for the park-people relationship: Insights from protected areas in Nepal and Myanmar. Int. J. Sust. Dev. World 2010, 17, 417-422. [CrossRef] 
83. Caldecott, J. Designing Conservation Project; Cambridge University Press: Cambridge, UK, 1995.

84. Piontek, F. Kontrowersje i Dylematy Wokót Rozwoju Zrównoważonego i Trwałego. Ekonomia a Rozwój Zrównoważony; Wydawnictwo Ekonomia i Środowisko: Bialystok, Poland, 2001.

85. Toruński, J. Aspekty środowiskowe zrównoważonego rozwoju obszarów prawnie chronionych. Zesz. Nauk. Akad. Podl. Siedl. 2010, 84, 21-32.

86. Weaver, D.B.; Lawton, L.J. A new visitation paradigm for protected areas. Tour. Manag. 2017, 60, 140-146. [CrossRef]

87. Leung, Y.F. Tourism and Visitor Management in Protected Areas: Guidelines for Sustainability; Spenceley, A., Hvenegaard, G., Buckley, R., Groves, C., Eds.; IUCN: Gland, Poland, 2018.

88. Eagles, P.F.; Bowman, M.E.; Tao, C.H. Guidelines for Tourism in Parks and Protected Areas of East Asia; IUCN: Gland, Poland, 2001.

89. Mandić, A. Structuring challenges of sustainable tourism development in protected natural areas with driving force-pressure-state-impact-response (DPSIR) framework. Environ. Syst. Decisions 2020, 1-17. [CrossRef]

90. Mandić, A.; Petrić, L. The impacts of location and attributes of protected natural areas on hotel prices: Implications for sustainable tourism development. Environ. Dev. Sustain. 2020, 1-31. [CrossRef]

91. Gałązka, M. Turystyka zrównoważona w parkach narodowych w opinii turystów. Stud. Mat. Cent. Eduk. Przyr. Leśn. 2009, 11, 123-130.

92. Para, A.K. Zasady zrównoważonego rozwoju turystyki-Bariery i szanse dla branży turystycznej. Zesz. Nauk. Tur. Rekr. 2013, 1. [CrossRef]

93. McMinn, S. The challenge of sustainable tourism. Environmentalist 1997, 17, 135-141. [CrossRef]

94. Apanowicz, J. Zarys Metodologii Prac Dyplomowych i Magisterskich z Organizacji i Zarządzania; Wyższa Szkoła Administracji i Biznesu: Gdynia, Poland, 1997.

95. Byrd, E.T. Stakeholders in sustainable tourism development and their roles: Applying stakeholder theory to sustainable tourism development. Tour. Rev. 2007, 62, 6-13. [CrossRef]

96. Liburd, J.J.; Edwards, D. (Eds.) Understanding the Sustainable Development of Tourism; Goodfellow: Oxford, UK, 2010.

97. Mihalič, T. Environmental management of a tourist destination: A factor of tourism competitiveness. Tour. Manag. 2000, 21, 65-78. [CrossRef]

98. Ceron, J.P.; Dubois, G. Tourism and sustainable development indicators: The gap between theoretical demands and practical achievements. Curr. Issues Tour. 2003, 6, 54-75. [CrossRef]

99. Huete-Alcocer, N.; López-Ruiz, V.R.; Grigorescu, A. Measurement of satisfaction in sustainable tourism: A cultural heritage site in Spain. Sustainability 2019, 11, 6774. [CrossRef]

100. McCool, S.F.; Bosak, K. (Eds.) Reframing Sustainable Tourism; Springer: Dordrecht, The Netherlands, 2016.

101. Wasiuk, A. Rachunkowość w zarządzaniu parkiem narodowym. Fin. Ryn. Fin. Ubezp. 2016, 80, $207-214$. [CrossRef]

102. Ustawa z Dnia 16 Kwietnia 2004 r. o Ochronie Przyrody, Dz.U. 2004 nr 92 poz. 880. Available online: http://prawo.sejm.gov.pl/isap.nsf/download.xsp/WDU20040920880/O/D20040880.pdf (accessed on 12 November 2019).

103. Kunasz, M. Zasoby przedsiębiorstwa w teorii ekonomii. Gosp. Nar. 2006, 211, 33-48. [CrossRef]

104. Ruśkowski, E.; Salachna, J.M. Finanse Publiczne. Komentarz Praktyczny; ODDK: Gdansk, Poland, 2014.

105. Government Republic of Poland. The Act on Public Finance; Government Republic of Poland: Warsaw, Poland, 2013.

106. Nasza Krajoznawczo Górska Przygoda. Available online: https://www.naszakgp.pl/ (accessed on 12 November 2019).

107. Berlin Declaration. Biodiversity and Sustainable Tourism. In Proceedings of the International Conference of the Ministers of the Environment, Berlin, Germany, 6-8 March 1997.

108. Local Data Bank of Statistics Poland. Available online: www.stat.gov.pl (accessed on 12 November 2019).

109. Szromek, A.R. Wskaźniki Funkcji Turystycznej. Koncepcja Wskaźnika Funkcji Turystycznej i Uzdrowiskowej; Wydawnictwo Politechniki Śląskiej: Gliwice, Poland, 2012.

110. Szromek, A.R. Pomiar funkcji turystycznej obszarów za pomoca wskaźników funkcji turystycznej na przykładzie obszarów państw europejskich. Stud. Ekon. 2013, 132, 91-103. 
111. Gios, G.; Goio, I.; Notaro, S.; Raffaelli, R. The value of natural resources for tourism: a case study of the Italian Alps. Int J Tour Res 2006, 8, 77-85. [CrossRef]

112. Bonzanigo, L.; Giupponi, C.; Balbi, S. Sustainable tourism planning and climate change adaptation in the Alps: A case study of winter tourism in mountain communities in the Dolomites. J. Sustain. Tour. 2016, 24, 637-652. [CrossRef]

113. Coban, G.; Yildiz, O.S. Developing a destination management model: Case of Cappadocia. Tour. Manag. Perspect. 2019, 30, 117-128. [CrossRef]

(C) 2020 by the authors. Licensee MDPI, Basel, Switzerland. This article is an open access article distributed under the terms and conditions of the Creative Commons Attribution (CC BY) license (http://creativecommons.org/licenses/by/4.0/). 